Revue de sciences sociales sur les arts, la culture et les idées

\title{
Repenser le concept d'autonomie pour la sociologie des biens symboliques
}

Rethinking the Concept of Autonomy for the Sociology of Symbolic Goods

Repensar el concepto de autonomía para una sociología de los bienes simbólicos

\section{Gisèle Sapiro}

\section{(2) OpenEdition \\ Journals}

Édition électronique

URL : http://journals.openedition.org/bssg/327

DOI : $10.4000 /$ bssg.327

ISSN : 2490-9424

Éditeur

Presses universitaires de Vincennes

Référence électronique

Gisèle Sapiro, "Repenser le concept d'autonomie pour la sociologie des biens symboliques », Biens Symboliques / Symbolic Goods [En ligne], 4 | 2019, mis en ligne le 27 juin 2019, consulté le 04 mars 2021. URL : http://journals.openedition.org/bssg/327 ; DOI : https://doi.org/10.4000/bssg.327 


\section{Repenser le concept \\ d'autonomie pour la sociologie des biens symboliques ${ }^{1}$}

\section{Rethinking the Concept of Autonomy for the Sociology of Symbolic Goods ${ }^{1}$}

\author{
Gisèle Sapiro \\ traduction | translation \\ Jean-Yves Bart
}

\begin{abstract}
Qu'entend-on par « autonomie » en sciences humaines et sociales ? Ce concept a des significations multiples qui entraînent parfois des confusions dans son maniement. La raison en est qu'elles renvoient à des traditions distinctes, de la problématique de l'autonomie politique, qui remonte à l'autonomia de la cité grecque antique, à celle de l'autonomie de l'individu, qui se développe avec l'éthique protestante et la pensée humaniste, et que Kant théorise sous le concept d'autonomie de la raison. Ce concept est également au cœur des réflexions sociologiques sur les conditions de production et de circulation des biens symboliques, sur lesquelles on se concentrera ici : il sert à analyser le rapport entre ces biens et les
\end{abstract}

1. Cet article est une version remaniée d'une communication présentée lors de la journée d'études « L'autonomie en questions » du RT27 de l'AFS, en février 2015, puis reprise pour une keynote lecture au colloque «Presumed Autonomy: Literature and the Arts in Theory and Practice » à l'Université de Stockholm, 10-13 mai 2016. Que David Armitage, Mathieu Hauchecorne et Richard Swedberg soient remerciés pour leur relecture et précieux commentaires sur cet article.
What is meant by "autonomy" in the human and social sciences? The concept's multiple meanings make it susceptible to mishandling. These meanings refer to distinct traditions, from the theme of political autonomy, which can be traced back to autonomia in Ancient Greek cities, to that of individual autonomy, a concern that grew along with the development of the Protestant ethic and humanist thought, as theorized in Kant's 'autonomy of reason.' Autonomy also holds a place of choice in sociological reflections on the conditions of production and circulation of symbolic goods, which will be the focus of this paper: it is used to analyse the relationship between these goods and economic, social, and political conditions, without

1. This article is a revised version of a paper first presented during the study day "L'autonomie en questions" [Autonomy in Questions] of the French Association of Sociology's thematic network RT27, and then developed as a keynote lecture at the conference 'Presumed Autonomy: Literature and the Arts in Theory and Practice,' University of Stockholm, 10-13 May 2016. Thanks to David Armitage, Mathieu Hauchecorne and Richard Swedberg for their reading and precious comments on this paper. 
conditions économiques, sociales et politiques, sans les y réduire. Mais là encore, ses acceptions varient entre les trois traditions qui en ont fait un usage systématique à partir des années 1950-1960, et où il a été discuté ${ }^{2}$ : la sociologie des professions, la théorie du reflet marxiste, et la théorie des champs (1). Nonobstant ces usages différenciés et partiellement incompatibles, il existe des zones de recoupement et des articulations possibles entre ces approches (2). Elles permettent de faire des propositions en vue d'une synthèse raisonnée de ces usages pour l'analyse sociologique de

la production et de la circulation des biens symboliques (3)

\section{Usages et significations du concept d'autonomie concernant la production et la circulation des biens symboliques}

Plus proche du sens politique dans la sociologie des professions, où il désigne la forme d'organisation des professions libérales, auxquelles l'État reconnaît une autonomie " technique » et organisationnelle (contrôle des recrutements et des pratiques) (1.1), le concept d'autonomie constitue dans la tradition marxiste un correctif à la théorie qui voit dans les œuvres d'art, comme dans la religion et l'État, une superstructure reflétant les rapports sociaux de production (1.2), alors que dans la théorie des champs, il s'agit de l'autonomie (relative) des univers de production par rapport aux contraintes externes, politiques, religieuses ou économiques (1.3).

2. II ne s'agit cependant pas ici de faire une histoire de ces débats, mais d'en retenir les éléments analytiques indispensables à la clarification des usages du concept d'autonomie. reducing goods to conditions. However, here too, meanings vary between the three strands of research that have systematically used and discussed it ${ }^{2}$ since the 1950-1960s: the sociology of professions, Marxist reflection theory, and field theory (1). Despite these differentiated, partly incompatible uses, there are overlap areas and possible bridges to cross between these approaches (2). They suggest proposals for a reasoned synthesis of these uses in sociological analysis of the production and circulation of symbolic goods (3).

\section{Uses and Meanings of the Concept of Autonomy Pertaining to the Production and Circulation of Symbolic Goods}

In the sociology of professions, the concept of autonomy is closer to the political sense of the word: it refers to the organizational form of professions whose 'technical' and organizational autonomy (over the control of access to the profession and practices) is recognized by the state (1.1). In the Marxist tradition, the concept of autonomy is a corrective to the theory that sees in artworks, as in religion and the state, a superstructure reflecting social relations of production (1.2), whereas in field theory, it refers to the (relative) autonomy of universes of production vis-à-vis external (political, religious, or economic) constraints (1.3)

2. This paper will not retrace the history of these debates; what is needed here is simply to pinpoint analytical elements that are indispensable to clarify the uses of the concept of autonomy. 


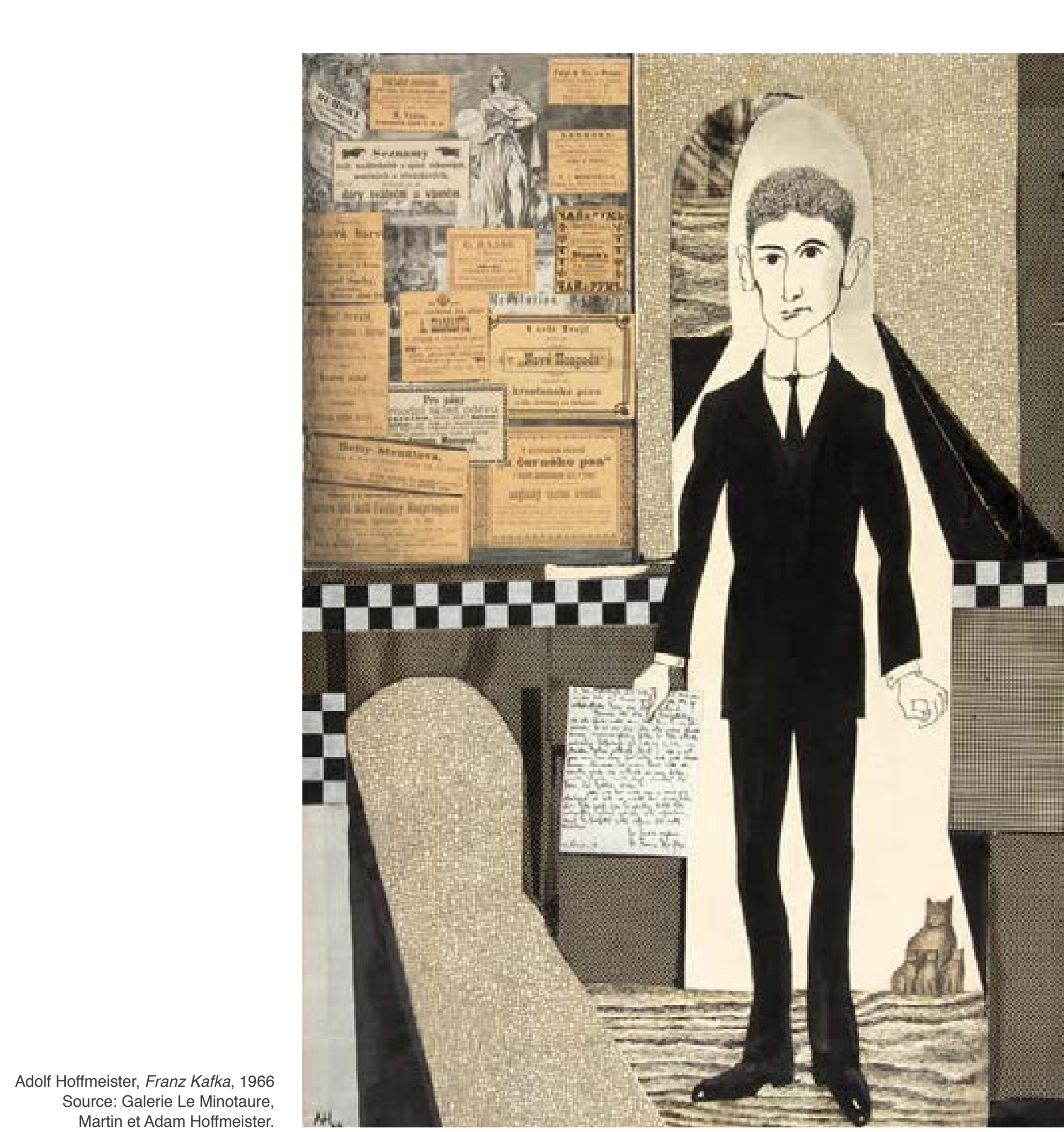




\subsection{La notion d'autonomie en sociologie des professions}

L'usage qu'a fait la sociologie des professions du concept d'autonomie renvoie à son acception politique d'autodétermination. Cet usage reprend la définition indigène de l'autonomie professionnelle, à savoir le droit et le privilège accordés par une entité gouvernementale à une classe de professionnels, et à chacun de ses membres certifiés, de dispenser des services sans contrôle. Au-delà de l'exercice de la profession, l'autonomie concerne l'organisation du groupe professionnel, son recrutement, ses règles de fonctionnement, son éthique, sa discipline intérieure. Pour les professions organisées ${ }^{3}$, l'autonomie résulte d'une délégation par l'État du pouvoir de décision et d'intervention aux instances représentatives, en particulier en ce qui concerne la définition des frontières du groupe, à savoir l'inclusion de nouveaux membres et l'exclusion ou la sanction de ceux qui contreviennent aux règles de la déontologie professionnelle.

La sociologie des professions anglo-américaine a constitué cette autonomie comme une des caractéristiques propres aux professions, universalisant les cas états-unien et britannique, à tradition libérale, où elle est codifiée dans la loi (pour les juristes et les médecins). Ces privilèges leur ont été octroyés en contrepartie de leur contribution au bien public. Dans son étude fondatrice sur la médecine, Eliot Freidson (1970 : 71-72, trad. fr. 1984) explique ainsi que seules les professions libérales ont obtenu le droit de contrôler leur propre travail et de déclarer illégitimes les évaluations extérieures. Selon Magali Sarfatti Larson (1977: XII), « cette autonomie distinctive n'est cependant que technique et non absolue. Les professions [libérales] dépendent en définitive du pouvoir de l'État, et elles ont émergé à l'origine grâce à l'aide de protecteurs puissants » [notre traduction].

3. On désignera par ce terme ce qu'on appelle en anglais les «professions », à savoir les métiers qui ont acquis une telle autonomie du point de vue de l'auto-organisation, et qu'on désigne en français sous l'expression de « professions libérales ». Les modes d'organisation ne se limitent cependant pas à cette forme libérale (voir infra)

\subsection{The Concept of Autonomy in the Sociology of Professions}

The use of the concept of autonomy in the sociology of professions relates to its political sense of self-determination. This is based on the indigenous definition of professional autonomy-namely, the right and privilege granted by a governmental entity to a class of professionals, and to each of its certified members, to offer services without being subject to control. Beyond the exercise of the profession itself, autonomy pertains to the organization of the professional group, its recruitment, rules of operation, ethics, and internal discipline. For these organized professions, ${ }^{3}$ autonomy is the result of the state's delegation of its powers of decision and intervention to representative bodies, particularly regarding the definition of the group's boundaries-i.e., the inclusion of new members and the exclusion or sanction of those who breach rules of professional conduct.

The Anglo-American sociology of professions made this autonomy one of the distinguishing characteristics of professions, by universalizing the cases of the US and the UK, informed by liberal traditions, where it was written into law (for lawyers and doctors). These privileges were granted to these professions in return for their contribution to the public good. In his pioneering study on medicine, Eliot Freidson (1970: 71-72) explains that only professions have been given the right to control their own work and to declare outside evaluation illegitimate. According to Magali Sarfatti Larson (1977: XII) "this distinctive autonomy is, however, only technical and not absolute. Professions ultimately depend upon the power of the state, and they originally emerge by the grace of powerful protectors."

3. I use this term to designate what is called in English the "professions," that is to say the occupations that have achieved autonomy of self-organization, the equivalent in French being professions libérales. However, the modes of organization are not limited to this liberal form (see below) 
L'histoire des professions montre toutefois que l'exercice de ces activités a pu prendre des formes différentes dans les États bureaucratiques et autoritaires : dans les empires français, allemand et habsbourgeois, une partie des services intellectuels, tels que l'enseignement, étaient assimilés à la fonction publique, ce qui permettait de les libérer des contraintes du marché et du clientélisme, et d'empêcher que les intérêts particuliers, économiques notamment, ne l'emportent sur l'intérêt général, tout en les contrôlant sur le plan idéologique (Siegrist 2004). Cette fonctionnarisation garantissait aux spécialistes un monopole mais les subordonnait à la hiérarchie. La situation des enseignant·e.s en France est toujours celle-là, mais un dispositif dérogatoire les soustrait à l'évaluation hiérarchique au profit de l'évaluation par les pairs - signe de l'autonomie qui leur est accordée - ; cette procédure prévaut aussi pour le recrutement de nouveaux entrants, autre indicateur de l'autonomie qui leur est concédée par l'État. Le modèle des officiers ministériels, qui existe en France pour les notaires et les commissaires-priseurs, combine autonomie relative et contrôle de l'État (Quemin 1997) ${ }^{4}$

Une telle perspective socio-historique comparée (Macdonald 1995) invite à inscrire la reconnaissance de l'autonomie professionnelle dans le cadre de l'histoire du " développement professionnel ${ }^{5}$ " telle que conçue par Andrew Abbott (1988) : une histoire incluant les luttes de concurrence entre professions pour obtenir le monopole de domaines de compétence reconnus par l'État (jurisdiction), qui est à l'origine de la « division du travail d'expertise ».

4. Issue de l'Ancien Régime, la profession de commissaire-priseur est restée très corporatiste, au sens de marché fermé, de régulation de la concurrence et de contrôle de la reproduction du corps (de père en fils le plus souvent).

5. Abbott propose ce terme à la place de celui, trop téléologique et unidimensionnel, de «professionnalisation ».
Yet the history of professions shows that the exercise of these activities has taken different forms in bureaucratic and authoritarian states: in the French, German, and Habsburg empires, some intellectual services, such as teaching, were considered part of the civil service, which freed them from market demands and clientelism, and ensured that individual interests, especially economic ones, did not prevail over the general interest, and were kept in check ideologically (Siegrist 2004). This affiliation with the civil service gave specialists a monopoly, but placed them under a hierarchy. The situation of university professors in France remains the same today, but a clause exempts them from hierarchical evaluation, which is replaced by peer evaluation-a sign of the autonomy granted to them; in a further sign, the recruitment of new professors works the same way. The system of officiers ministériels [ministerial officers], which applies to notaries and auctioneers in France, combines relative autonomy and state control (Quemin 1997). ${ }^{4}$

Such a comparative socio-historical perspective (Macdonald 1995) calls for an embedding of the recognition of professional autonomy within the framework of the history of "professional development" conceptualized by Andrew Abbott (1988) - a history that includes the competitive struggles between professions over the monopoly of staterecognized areas of expertise ("jurisdiction"), leading to the "division of expert labour."

4. Established before the French Revolution, the profession of auctioneer has remained highly corporatist - characterized by a closed market, the regulation of competition, and control over the reproduction of the body (generally from father to son).

5. Abbott favours this term over "professionalization," which he considered too teleological and unidimensional. 
L'approche comparative (entre professions et entre pays) soulève aussi la question de la circulation du modèle professionnel. Par exemple, en France, l'organisation professionnelle est importée du monde anglo-américain sous la Troisième République (1870-1940), dans une double conjoncture de libéralisation (une loi autorisant les syndicats est votée en 1884 , les associations sont rendues légales par la loi de 1901) et de laïcisation, qui voit la religion supplantée par le nationalisme comme vecteur identitaire, et par la science comme source de connaissance et de vérité (Sapiro 2006). Les médecins acquièrent à cette époque une autorité sociale consacrée par l'État (notamment face au clergé) (Léonard 1987 : 5-19). D'autres professions s'organisent à cette époque en France, notamment les journalistes (Delporte 1998) et les ingénieurs-conseils (Henry 2012).

Le degré d'autonomie accordé aux professions varie cependant selon les régimes, les plus autoritaires tendant à la réduire autant que possible, comme l'illustre le cas des professions d'ingénieur et d'enseignant sous le nazisme (Jarausch 1990), ou celui des médecins sous le régime de Vichy (Muel-Drefyus 1998 : 301 sq).

Analysant, dans son étude sur la médecine, les fondements de l'autonomie professionnelle, Eliot Freidson suggérait d'y voir, plutôt qu'un trait intrinsèque, le résultat d'un processus, une conquête qui permet aux professionnels d'acquérir une certaine indépendance eu égard à l'idéologie des élites dominantes, mais qui n'est pas acquise une fois pour toute et peut se perdre, l'autonomie étant concédée par l'État. II distingue l'autonomie technique, fondée sur des savoirs ésotériques ou complexes, de l'autonomie quant aux conditions socio-économiques. C'est la première qui constitue un critère de différenciation entre les professions libérales et les autres métiers : elle est reconnue aux médecins quelles que soient leurs conditions de travail (y compris en Union soviétique), et conditionne en bonne partie l'autonomie socio-économique (Freidson 1970 : 23-24, 45, trad. fr. 1984)
The comparative approach (between professions and countries) also raises the question of the circulation of professional models. In France, for instance, the professional organization was imported under the Third Republic (1870-1940), against a background of liberalization (a law authorizing unions was passed in 1884, and associations were made legal in 1901) and secularization, wherein religion was replaced by nationalism as a vector of identity, and by science as a source of truth and knowledge (Sapiro 2006). At the time, doctors acquired a state-sanctioned social authority (especially vis-à-vis the clergy) (Léonard 1987: 5-19). Other professions were structured during that period, including journalism (Delporte 1998) and consulting engineers (Henry 2012).

However, the degree of autonomy granted to professions varies between regimes. The most authoritarian regimes tend to reduce autonomy as much as possible, as illustrated by the cases of the professions of engineer and teacher in Nazi Germany (Jarausch 1990), or doctor under the Vichy regime in France (Muel-Drefyus 1998: 301 sq.).

Eliot Freidson analysed the foundations of professional autonomy in his study on medicine. Rather than conceiving it as an intrinsic trait, he argued that autonomy was the outcome of a process, a conquest allowing professionals to acquire independence from the ideology of the dominant elites, but which is not acquired once and for all, and as such can be lost-since indeed autonomy is granted by the state. $\mathrm{He}$ introduces a distinction between technical autonomy, based on esoteric or complex knowledge, and socio-economic autonomy The former constitutes a criterion for differentiating professions and other occupations: it is recognized in doctors, irrespective of their working conditions (including in the USSR) and largely conditions socio-economic authority (Freidson 1970: 23-24; 45). 
II faut préciser que, là où elle existe, cette autonomie a souvent été accordée en échange du service du pouvoir : par exemple, la reconnaissance de la médecine comme profession libérale en France est étroitement liée à la reconnaissance de l'expertise des hygiénistes et à la capacité des médecins à assurer l'ordre et la salubrité publiques (Goldstein 1984). L'autonomie sous-tend aussi le pouvoir, l'autorité exercée par les professionnels sur les clients, les « profanes ", comme l'ont pointé, à la suite de Freidson (1970, trad. fr. 1984), les travaux critiques des années 1970 (Sarfatti Larson 1977). En effet, l'autonomie technique accordée par l'État permet aux professionnels d'exercer un monopole du savoir dans leur territoire de compétence et de ne pas être soumis à un contrôle externe du point de vue des contenus. Cette technicité fonde leur autorité. Elle s'exprime dans un langage particulier, appelé « jargon », et qui a, selon Terence Johnson (1970 : 56), une double fonction : maintenir l'homogénéité interne du groupe professionnel et accroître l'autonomie à l'égard des extérieurs, aussi bien les concurrents potentiels que sont les spécialistes d'autres domaines que les profanes. Ainsi, comme il le souligne (Johnson 1970 : 57), c'est le professionnalisme qui engendre le charlatanisme (au cours des luttes pour la conquête du monopole de leur domaine de compétence), et non l'inverse.

Les métiers de création ne bénéficient pas d'un tel statut professionnel. Ils sont rarement pris en considération par la sociologie des professions, sauf comme un " défi ", selon l'expression de Freidson (1986). En effet, s'ils partagent avec les professions organisées certains traits, comme l'existence d'instances représentatives, ces métiers manquent d'autres attributs tels qu'une formation spécifique certifiée par un diplôme dans le cas des écrivains ou de beaucoup d'artistes, ou encore un code de déontologie pour la plupart d'entre elles. Néanmoins, la sociologie de l'art s'est constituée en partie en abordant les activités artistiques sous l'angle des carrières de créateurs (Moulin 2009), de la division du travail (Becker 1980) et de
Worth noting is that, where it exists, this autonomy was often granted in return for serving the authorities: for instance, the recognition of medicine as a profession libérale in France was closely linked to the recognition of the expertise of hygienists and the ability of doctors to ensure public order and health (Goldstein 1984). Autonomy also involves power, the authority of professionals over the "lay" clientele-as critical studies that built on the work of Freidson (1970) in the 1970s noted (Sarfati Larson 1977). Indeed, the technical autonomy granted by the state allows professionals to exercise a monopoly over knowledge in their jurisdiction and to not be subjected to outside control of content. This technicity is the basis of their authority. It is expressed in a distinct language: "jargon," which according to Terence Johnson (1970: 56) has the double function of maintaining the professional group's internal homogeneity and "increasing autonomy from outsiders, both competing specialists and laymen." As Johnson (1970: 57) points out, it is professionalism that creates charlatanism (in the course of the struggles over the monopoly in an area of expertise), not the other way around.

Creative jobs do not enjoy such professional status. They are rarely taken into consideration by the sociology of professionswhen they are, this is a "challenge," to quote Freidson's phrase (1986). While they do share some characteristics with organized professions, including the existence of representative bodies, these occupations lack other attributes, such as a specific training programme attested by a diploma in the case of writers and many artists, or a code of ethics in most cases. Nevertheless, the sociology of art was founded partly by addressing artistic activities from the perspective of creators' careers (Moulin 2009), the division of labour (Becker 1980), and professionalization. Raymonde 
la professionnalisation. Raymonde Moulin $(1967 ; 1983)$ a analysé les transformations des organisations de la vie artistique, de l'organisation corporative $\mathrm{au} \mathrm{XIV}^{\mathrm{e}}$ siècle, à l'académisme $\mathrm{au} \mathrm{xVII}{ }^{\mathrm{e}}$ siècle, puis à la professionnalisation paradoxale avec l'avènement du marché, lequel substitue à la compétence certifiée par l'Académie des beaux-arts la vocation, reconnue par les intermédiaires que sont désormais les galeristes. Philippe Coulangeon (1999) montre, de son côté, que la professionnalisation (inaboutie) des musiciens de jazz, et donc leur différenciation des amateurs, a été relayée, dans le cas français, par un ensemble d'acteurs extérieurs à cette communauté.

C'est une question tout à fait différente que pose Robert Merton dans son analyse des scientifiques : celle de l'incompatibilité entre l'éthique de la science et l'idéologie étatique en régime autoritaire (Merton 1996). Comment la science peut-elle demeurer autonome dans une telle conjoncture ? L'idée d'autonomie scientifique suppose que les professionnels sont en mesure d'échapper à ces diktats politiques. Ceci rapproche Merton de la problématique marxiste - dont il tire cette idée d'une marge d'autonomie de la sphère de connaissance (Merton 1996 : 257) -, comme de la théorie du champ - dont il est une des sources. Suivant Marx, Karl Mannheim inscrit cette autonomie dans la position des intellectuels «flottant librement", " sans attaches " dans la structure sociale (ou : " intelligentsia socialement désancrée ", selon la nouvelle traduction française Mannheim 2006 : 128). Cette réflexion a inspiré la sociologie de la connaissance, de Merton (1996 : 267-277 : réflexion sur l'ethos des scientifiques) à Bourdieu (1975; 2001 : autonomie relative du champ scientifique), mais n'a pas été reprise par les penseurs marxistes. Merton a en revanche été critiqué par les tenants du « programme fort » en sociologie des sciences pour avoir dissocié les dimensions cognitives de l'activité scientifique de ses dimensions sociales (Barnes, Bloor, Henry 1976 ; Callon \& Latour 1982 ; voir aussi la synthèse d'Olivier Martin 2005). C'est précisément cette tension entre enjeux sociaux et enjeux cognitifs que le concept de champ vise à dépasser (Bourdieu 2001 ; voir infra).
Moulin $(1967,1983)$ analysed transformations in the organizations of artistic life in France, from corporative organization in the fourteenth century, to academism in the seventeenth century, and paradoxical professionalization with the emergence of the market, which replaced skill-certified by the academy of fine arts-by vocation, recognized by new intermediaries: gallery managers. Philippe Coulangeon (1999), for his part, showed that in France the (unfinished) professionalization of jazz musicians, and by extension their differentiation from amateurs, has been supported by a range of actors outside the community.

Robert Merton raises a wholly different question in his analysis of scientists - that of the incompatibility between the ethics of science and state ideology in authoritarian regimes (Merton 1996). How can science remain autonomous in such settings? The idea of scientific autonomy requires professionals to be able to escape political diktats. This brings Merton closer to the Marxist problematic-from which he draws the idea of a margin of autonomy of the sphere of knowledge (Merton 1996: 257) -, and to field theory-of which he was one of the sources. After Marx, Karl Mannheim inscribed this autonomy in the position of "unanchored, relatively classless," "free floating" intellectuals (or "socially unattached intelligentsia," in Mannheim 2006: 128). This insight inspired the sociology of knowledge, from Merton's considerations on the scientist's ethos (1996: 267-277) to Bourdieu's on the relative autonomy of the scientific field $(1975 ; 2004)$, but was not picked up by Marxist thinkers. Merton was on the other hand criticized by the advocates of the Strong Programme in the sociology of science, for having dissociated the cognitive and social dimensions of scientific activity (Barnes, Bloor, Henry 1996; Callon \& Latour 1991; see also Olivier Martin's 2005 synthesis). The concept of field precisely aimed to overcome this tension between the cognitive and the social (Bourdieu 2004; see below). 


\subsection{La conception marxiste de l'autonomie des œuvres}

Dans la pensée marxiste, la notion d'autonomie est apparue initialement comme un correctif à la théorie du reflet. Selon le postulat matérialiste, la littérature, à l'instar de la religion, participe de la superstructure, qui reflète les rapports de production. Apparue d'emblée comme réductrice, la théorie du reflet a néanmoins donné lieu à une riche réflexion sur l'autonomie des œuvres par rapport aux conditions sociales et sur les médiations entre elles (Goldmann 1970 ; Macherey 1971 ; Williams 1977 ; voir la synthèse de Sayre 2011). La littérature est-elle un simple reflet du monde social, comme le revendique la littérature réaliste, ou l'expression d'une idéologie que véhicule la " vision du monde » (Weltanschauung) ? Pour Mannheim (2006), l'idéologie est en effet une vision du monde, la structure de conscience d'un groupe social ou son style de pensée ; elle se subdivise en deux catégories : l'idéologie qui légitime l'ordre établi et favorise ainsi sa reproduction, et l'utopie, terme désignant les représentations ayant une fonction subversive. D'autres penseurs se sont demandé si la « vision du monde » véhiculée par les œuvres littéraires et artistiques est la manifestation de la conscience collective de la classe dominante ou si elle fait écho aux contradictions qui travaillent les rapports sociaux de production. Expression de ces contradictions, l'œuvre de Balzac peut ainsi livrer un regard critique sur la société indépendamment des positions politiques de l'auteur, explique Georg Lukács (1999 [1951]).

En prenant appui sur les travaux de ce dernier, pour qui les rapports entre les formes littéraires et les situations sociales où elles sont nées sont médiatisées par la conscience collective, le sociologue Lucien Goldmann (1955) considère que le vrai sujet de l'œuvre n'est pas l'auteur individuel mais le groupe social auquel il appartient (famille, profession, nation, classe). La vision du monde du groupe constitue la médiation entre l'infrastructure économique et sociale et

\subsection{The Marxist Conception of the Autonomy of Artworks}

In Marxist thought, the concept of autonomy emerged as a corrective to reflection theory. Under the materialistic postulate, literature contributes, as does religion, to the superstructure, which reflects relations of production. While it appeared reductive from the outset, reflection theory inspired in-depth consideration of the autonomy of artworks from social conditions and on the mediations between them (Goldmann 1970; Macherey 1971; Williams 1977; for a synthesis, see Sayre 2011). Is literature merely a reflection of the social world, as realist literature claims to be, or the expression of an ideology through a "world vision" or "worldview" (Weltanschauung)? For Mannheim (2006), ideology is indeed part of a worldview, a social group's structure of consciousness or style of thought, divided into two categories: ideology, which legitimates the established order and facilitates its reproduction; and utopia, which refers to representations with a subversive function. Other thinkers have asked whether the "worldview" conveyed by literary and artistic worlds is the manifestation of the dominant class's collective consciousness or if it echoes the contradictions at work in social relations of production. As the expression of these contradictions, Georg Lukács (1951/1999) contended, Balzac's work may for instance give us a critical outlook on society regardless of the author's political positions.

Drawing on research by Lukács, who argued that the relations between literary forms and the social situations in which they emerged are mediated by collective consciousness, sociologist Lucien Goldmann (1955 Engl. ed. 2013) considered that the real subject of the work is not the individual author, but the social group to which he or she belongs (family, profession, nation, and class). The group's worldview constitutes the mediation between the 
les œuvres : « Une vision du monde, c’est précisément cet ensemble d'aspirations, de sentiments et d'idées qui réunit les membres d'un groupe (le plus souvent, d'une classe sociale) et les oppose aux autres groupes » (Goldmann $1955: 26)$. Les membres du groupe réalisent cette conscience « d'une manière plus ou moins consciente et cohérente ", à partir d'une " situation économique et sociale qui engendre une activité dont le sujet est la communauté, réelle ou virtuelle, constituée par la classe sociale » (Goldmann $1955: 27)$. II y a ainsi une homologie structurale entre les tragédies de Racine ou Les Pensées de Pascal et la vision « tragique » du monde des jansénistes, qui est une expression de la conscience collective de la noblesse de robe. Le premier jansénisme émerge en effet au moment du passage de la monarchie tempérée à la monarchie absolue, parmi les officiers (notamment les avocats) qui dépendent de l'État et ne peuvent par conséquent développer une opposition active, bien qu'ils prennent leurs distances. Leur vision tragique est une idéologie - ou plutôt « vision totale » englobant idéologie, affectivité et comportement - qui affirme " l'impossibilité radicale de réaliser une vie valable dans le monde » (Goldmann $1955: 117^{6}$ ). Goldmann considère la littérature, de même que les arts, la philosophie, et dans une grande mesure la pratique religieuse, comme des "langages ", des " moyens de l'homme de communiquer avec d'autres êtres ", dont la spécificité est qu'ils sont réservés à l'expression de contenus particuliers, à savoir les "visions du monde ", lesquelles sont des " extrapolations conceptuelles jusqu'à l'extrême cohérence des tendances réelles, affectives, intellectuelles et même motrices des membres d'un groupe. C'est un ensemble cohérent de problèmes et de réponses qui s'exprime, sur le plan littéraire, par la création à l'aide de mots, d'un univers concret d'êtres et de choses " (Goldmann 1955 : 347-349). C'est pourquoi, selon Goldmann :

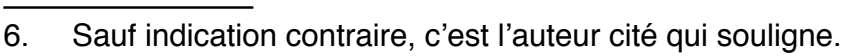

economic and social infrastructure and the works: "A world vision is [...] the whole complex of ideas, aspirations and feelings which links together the members of a social group (a group which, in most cases, assumes the existence of a social class), and which opposes them to members of other social groups" (Goldmann 2013: 17). The members of the group attain this consciousness "in a more or less coherent manner," "as a result of a particular social and economic situation, and which then gives rise to the set of activities performed by the real or potential community constituted by this social class" (Goldmann 2013: 18). There is thus a structural homology between Racine's tragedies or the Pensées of Pascal and the "tragic" world vision of the Jansenists, an expression of the collective consciousness of the noblesse de robe. The first form of Jansenism indeed emerged at the time of the shift from limited to absolute monarchy, among the officers (especially lawyers) who depended on the state and could therefore not commit to active opposition, although they did distance themselves. Their tragic vision is an ideology-or rather a "total vision" encompassing ideology, affect, and behaviour-asserting that it is "impossible to live a valid life in this world" (Goldmann 2013: 1056). Goldmann sees literature, like the arts, philosophy, and to a large extent religious practice, as a "language"-a means for men to communicate with other beings, whose defining feature is that they are dedicated to the expression of specific contents, i.e., "world visions"-a world vision being "the conceptual extrapolation in the most coherent manner possible of the real, emotional, intellectual, and even motor tendencies of the members of a group. It is a coherent pattern of problems and replies which is expressed, on the literary plane, by the creation through words of a concrete universe of beings and things." (Goldmann 2013 [1955]: 314) This is why, according to Goldmann:

6. Author's emphasis unless indicated otherwise. 
Le fait esthétique consiste en deux paliers d'adéquation nécessaire :

Celle entre la vision du monde comme réalité vécue et l'univers créé par l'écrivain

Celle entre cet univers et le genre littéraire, le style, la syntaxe, les images, bref, les moyens proprement littéraires qu'a employés l'écrivain pour l'exprimer.

La « cohérence » de l'extrapolation fait selon lui la valeur des œuvres littéraires, par comparaison à d'autres écrits : « toutes les œuvres littéraires valables sont cohérentes et expriment une vision du monde » (Goldmann 1955 : 349). Cette capacité d'extrapolation, qui fonde à ses yeux la représentativité, est réservée à quelques

individus singuliers.

Les théoriciens de l'école de Francfort se sont également confrontés à la problématique du reflet. Dans ses Notes sur la littérature (2009 [1958]), Adorno constate que l'art le plus hermétique peut exprimer une réaction contre la langue « avilie par le commerce ». Mais en insistant sur l'ambiguïté des textes littéraires, leur polysémie, il montre aussi qu'ils résistent à la réduction idéologique.

Cependant, contre l'idée d'une mystification des masses par les productions des industries culturelles, qui aliénerait la conscience de classe ouvrière, les fondateurs des Cultural Studies développent au même moment une réflexion sur les rapports entre culture et société qui tient compte de la médiation des conditions de production et de réception. Si, avec la notion d'《 attention oblique », Richard Hoggart (1970 [1957] : 296) remet en cause la conception d'une réception passive de ces produits par les classes populaires, Williams (1965) étudie les effets de la révolution industrielle sur la littérature avant de mettre en place un programme de sociologie historique des institutions de la vie littéraire (Williams 1977, 1981).
"The aesthetic fact consists of two levels of necessary correspondence:

(1) the correspondence between the world vision as an experienced reality and the universe created by the writer; and

(2) the correspondence between this universe and the specifically literary devices-style, images, syntax, etc.used by the writer to express it."

In his view, the "coherence" of the extrapolation is what gives literary works value compared with other writings: "All valid literary works have an inner coherence and express a world vision" (Goldmann 2013 [1955]: 315). This capacity of extrapolation, which is to him the basis of representativeness, is only found in a few singular individuals.

Frankfurt School theoreticians also tackled the reflection problem. In his Notes to Literature (1958), Adorno (1992) argued that the most hermetic art can express a reaction against the devastation of language by commerce. However, as he emphasizes the ambiguity and polysemy of literary texts, he also shows that they resist ideological reduction.

At the same time, against the idea of a mystification of the masses by the productions of the cultural industries, alienating workingclass consciousness, the founders of Cultural Studies considered the relations between culture and society with special attention to the mediation of conditions of production and reception. While, with the notion of "oblique attention" Richard Hoggart (1957/1970: 296) challenged the view that working-class people passively received these products, Williams (1961) studied the effects of the Industrial Revolution on literature and developed a programme for the historical sociology of the institutions of literary life (Williams 1977; 1981). Whereas in Goldmann's work, the mediation between 
Alors que pour Goldman, c'est la vision du monde qui constituait une médiation entre l'infrastructure économique et sociale et l'œuvre, chez Williams, ce sont les conditions sociales de production des œuvres. Pourtant, Williams nie la distinction entre la littérature et les autres formes d'écriture.

Le concept de « production " se diffuse alors pour remplacer l'idéologie romantique de la création. Pour Pierre Macherey (1971: 53-54), l'œuvre est, en effet, le « produit d'un travail » et l'écrivain un « ouvrier de son texte » qui « ne fabrique pas les matériaux avec lesquels il travaille ». II conçoit néanmoins l'œuvre comme un « miroir brisé » qui ne reflète pas parfaitement la réalité. Macherey récuse en même temps une approche purement matérialiste des conditions de production, à l'instar de son maître, Louis Althusser. Celui-ci plaide en effet pour l'élaboration d'une réflexion scientifique sur « les processus qui produisent "l'effet esthétique" d'une œuvre d'art », comme il l'explique dans le numéro d'avril 1966 de la revue intellectuelle communiste La Nouvelle Critique (Matonti 2005 : 174). Claude Prévost engage alors une réflexion sur la critique littéraire qui vise à sortir de la problématique du réalisme pour dépasser la théorie du reflet, identifiée à Lukács, et focalisée sur le contenu des œuvres, au détriment de la forme (voir Matonti 2005 : 172-175). II récuse aussi la notion de "fait artistique ", invitant la critique à se recentrer sur l'analyse du langage. Dans le numéro d'avril 1967 de La Nouvelle Critique, alors engagée dans un aggiornamento théorique (Matonti 2005), il publie un article intitulé « Marx et les mythes ", qui critique l'interprétation que fait Roger Garaudy de L'Introduction générale à la critique de l'économie politique, texte où Marx interroge la pérennité de l'émotion esthétique, le " charme » persistant de l'œuvre d'art par-delà ses conditions de production. Marx introduit ainsi, d'après Garaudy, une « autonomie relative » de l'œuvre permettant de dépasser la notion de reflet. Or Prévost voit dans l'interprétation de Garaudy une forme d'idéalisme. II met quant à lui l'accent sur la fonction « démythifiante » de la littérature et du langage littéraire. the economic and social infrastructure and the work was the world vision, in Williams the social conditions of production of the works take on that role. Nonetheless, Williams denied the distinction between literature and other forms of writing.

The concept of "production" spread and replaced the romantic ideology of creation. To Pierre Macherey (1971: 53-54), for instance, a literary work is indeed the "product of work" and the writer is a "worker of his text," who "does not manufacture the materials with which he is working." Yet Macherey sees the work as a "broken mirror," imperfectly reflecting reality. At the same time, Macherey refused a purely materialistic approach to conditions of production, like his mentor, Louis Althusser. The latter indeed called for scientific reflection on "the processes that produce the 'aesthetic effect' of an artwork" in the April 1966 issue of the communist intellectual journal La Nouvelle critique (see Matonti 2005: 174). Claude Prévost then looked for a way out of the problem of realism in order to overcome reflection theory, identified with Lukács, and focused on content, to the detriment of form (see Matonti 2005: 172-175). He also recused the concept of "artistic fact," and called on criticism to refocus on the analysis of language. In the April 1967 issue of La Nouvelle Critique, which was going through a theoretical aggiornamento (Matonti 2005), he published a piece on "Marx and myths," in which he criticized Roger Garaudy's interpretation of the introduction to Contribution to the Critique of Political Economy, in which Marx questioned the permanence of aesthetic emotion, and the "charm" of artworks, beyond their conditions of production. According to Garaudy, Marx had introduced a "relative autonomy" of the work there, allowing us to overcome the idea of reflection. Prévost, however, saw in Garaudy's interpretation a form of idealism. For his part, he emphasized the "demythifying" function of literature and literary language. 
Dans Lire le Capital (1965), le philosophe marxiste Althusser et ses disciples, Étienne Balibar, Roger Establet, Pierre Macherey et Jacques Rancière, récusent les notions de causalité qui soustendent les analyses marxistes : d'un côté, la causalité mécanique présupposée par la théorie du reflet, de l'autre, la causalité expressive impliquée par le concept de « vision du monde ", les textes étant lus comme des modèles allégoriques de la société dans son ensemble (chez Lukács, par exemple). Associé à la causalité expressive, le concept même de médiation est problématique de leur point de vue, en ce qu'il établit des relations entre différents niveaux (superstructure et infrastructure, texte et société). Ils proposent de substituer à ces deux types de causalité l'idée d'une " causalité structurale ", à savoir la présence de la structure, son immanence, dans ses effets mêmes, à l'instar du concept de Darstellung dans la théorie marxiste de la valeur. La notion d'« appareils idéologiques d'État » proposée par Althusser (1970) permet de théoriser l'idée d'une autonomie relative de la superstructure par rapport à l'infrastructure qui la détermine et de l'effet en retour qu'elle peut avoir sur cette dernière, à savoir la « reproduction », qu'il illustre à travers le rôle de l'école.

Dans The Political Unconscious, le critique marxiste états-unien Fredric Jameson (1981, trad. fr. 2012) démontre néanmoins que, dans le domaine littéraire, ces deux types de causalité mis en cause par Althusser conservent une validité locale : le remplacement du modèle dominant du roman en trois volumes par un format de volume unique moins onéreux à la suite de la crise qu'a traversée l'édition à la fin du XIX ${ }^{e}$ siècle (cause externe) n'a-t-il pas entraîné une modification de la forme même du récit romanesque ? Et si la causalité expressive ou allégorique fonctionne à un certain niveau, c'est parce que les grands récits ou les conceptions prédominantes de l'histoire sont souvent inscrits dans les textes mêmes. Ces derniers sont même, avance Jameson, notre principal intermédiaire vers une historicité autrement
In Lire le Capital (1965 Engl. ed. 2015), Marxist philosopher Louis Althusser and his disciples Étienne Balibar, Roger Establet, Pierre Macherey, and Jacques Rancière rejected the notions of causality underlying Marxist analyses - on the one hand, the mechanic causality presupposed by reflection theory, and on the other, the expressive causality entailed by the concept of "world vision," which meant reading texts as allegorical models of society as a whole (for instance in Lukács's work). They argued that associated with expressive causality, the very concept of mediation is problematic in that it establishes relations between different levels (superstructure and infrastructure, text and society). They proposed replacing these two types of causality with the idea of a "structural causality," referring to the presence and immanence of the structure in its very effects, akin to the Darstellung concept in the Marxist theory of value. The concept of 'ideological State apparatuses' introduced by Althusser (1970 Engl. ed. 1984) was a means to theorize the idea of a relative autonomy of the superstructure from the infrastructure that determines it, and of the effect it may have in return on the latter, namely "reproduction," which he illustrates by discussing the role of school.

In The Political Unconscious, US Marxist critic Fredric Jameson (1981) showed that in the literary domain, the two types of causality challenged by Althusser remain locally valid: indeed, did the replacement of the dominant model of the three-volume novel by the cheaper single-volume format following the late nineteenth century crisis of publishing (an external cause) not lead to altering the very form of novelistic narrative? And expressive or allegorical causality works on some level because the great narratives and leading conceptions of history are often inscribed in the texts themselves. According to Jameson, these texts are actually our main pathways to access an otherwise inaccessible historicity, which functions as an absent cause (this is how Althusser interprets Spinoza's 
inaccessible, qui fonctionne comme une cause absente (c'est ains qu'Althusser interprète l'immanentisme de Spinoza : les effets sont inhérents à la structure - ou à Dieu). C'est en cela qu'ils constituent des sources pour appréhender notre "inconscient politique », lequel doit être l'objet du travail d'interprétation. Selon Jameson, la principale contribution d'Althusser réside dans l'autonomie relative qu'il reconnaît aux différentes sphères sociales, contre la causalité expressive qui tend à les réduire les unes aux autres au moyen des concepts d'homologie structurale (par exemple, chez Goldmann, entre la situation de classe, la vision du monde et les formes artistiques, ou entre le roman comme forme et la vie quotidienne de la société individualiste née de l'économie de marché) ou de médiations (l'institution familiale comme médiation entre l'expérience de l'enfant et la structure de classe dans la biographie que Sartre consacre à Flaubert). Mais, comme le souligne Jameson, la notion même d'autonomie relative ne peut se passer d'une réflexion sur les formes de médiation entre les différentes sphères.

\subsection{Le concept d'autonomie dans la théorie des champs}

C'est Pierre Bourdieu qui a pleinement théorisé la notion d'autonomie relative des sphères d'activité, avec le concept de champ. S'il emprunte ce concept à la réflexion marxiste, c'est pour lui donner un sens différent, en l'articulant avec la conception wébérienne de la différenciation des espaces sociaux du fait de l'émergence d'un corps de spécialistes (les juristes dans le cas du droit) et avec l'analyse durkheimienne de la division du travail. Bourdieu s'inspire également du programme tracé par Levin L. Schücking (1931) qui, dans sa Sociologie du goût littéraire, s'intéresse aux instances propres au monde des lettres. Précisons qu'aucun de ces auteurs n'emploie le concept d'autonomie. Cette notion paraît même incompatible avec la conception fonctionnaliste de la solidarité organique qui sous-tend la division sociale du travail selon Durkheim. Elle est en revanche immanentism: effects are inherent in the structure-or in God). It is in that sense that they are sources to access our "political unconscious," which must be subject to the work of interpretation. According to Jameson, Althusser's main contribution resides in the relative autonomy he recognizes in the different social spheres, against expressive causality, which tends to reduce them to one another through the concepts of structural homology (for instance, in Goldmann's work, between class situation, world vision, and artistic forms, or between the novel as a form and the everyday life of the individualistic society resulting from the market economy) or mediation (the institution of family as a mediation between the child's experience and the class structure, in Sartre's biography of Flaubert). However, as Jameson notes, the very concept of relative autonomy cannot be used without reflecting on the forms of mediation between different spheres.

\subsection{The Concept of Autonomy in Field Theory}

Pierre Bourdieu proposed a comprehensive theory of the relative autonomy of spheres of activity with the concept of field. While he borrowed the notion of autonomy from Marxist thought, he gave it a different meaning, by linking it to Weber's conception of the differentiation of social spaces as a result of the emergence of a body of specialists and to Durkheim's analysis of the division of labour. Bourdieu was also inspired by the programme laid out by Levin L. Schücking (1931) who, in his Sociology of Literary Taste, addressed the role of authorities specific to the world of literature. It should be noted that none of these authors used the concept of autonomy, which actually seems incompatible with the functionalist conception of organic solidarity that underpins the social division of labour according to Durkheim. However, it can be reconciled with 
tout à fait conciliable avec celle, wébérienne, de différenciation de domaines se dotant de références et de règles propres, que Parsons (1939), puis Luhmann (1991) ont développée dans une approche systémique fonctionnaliste. Chez Weber, le concept de Eigengesetzlichkeitpar lequel il caractérise les Wertsphären, sphères de valeur (religieuse, économique, politique, esthétique, érotique dans la " Considération intermédiaire ", "Zwischenbetrachtung 》, parue en 1915 et reprise dans ses écrits sur la sociologie des religions) ou Lebensordnungen (ordres de vie), renvoie à une logique intrinsèque ou, selon Roth (1992 : 457), une " autonomie » émergeant du processus de différenciation de ces sphères sur le plan des valeurs - susceptibles d'entrer en conflit - et des institutions (voir aussi l'entrée « value-spheres » dans Swedberg \& Agevall 2016). La réflexion d'Ernst Cassirer (autre source de la théorie des champs) sur les formes symboliques - langage, science, religion, mythes, arts postule aussi leur autonomie et leur incompatibilité partielle, qui les rend irréductibles à la logique (il parle, par exemple, du « système conceptuel » - «Begriffswelt » - de la physique comme d'un « monde entièrement clos sur lui-même » ; Cassirer 1972 : 26).

Chez Bourdieu, la réflexion sur l'autonomie est née d'une question méthodologique : peut-on autonomiser les domaines culturels comme objets d'étude ? Or une telle opération n'est selon lui possible qu'à condition d'étudier le processus historique d'autonomisation de ces espaces d'activité (qu'il s'agisse du champ littéraire, du champ artistique, du champ scientifique, etc.) : « Une telle démarche n'est fondée, cela va de soi, que dans la mesure où l'objet auquel elle s'applique, à savoir le champ intellectuel (et par là le champ culturel), est doté d'une autonomie relative, autorisant l'autonomisation méthodologique qu'opère la méthode structurale en traitant le champ intellectuel comme un système régi par ses lois propres ", écrit-i dès son tout premier article sur la question, "Champ intellectuel et projet créateur » (Bourdieu 1966 : 866). Si la structure du champ
Weber's analysis of the differentiation of domains endowed with their own references and rules, elaborated upon by Parsons (1939) and Luhmann (1991) in a functionalist systemic approach.

In Weber's work, the concept of Eigengesetzlichkeit serves to characterize the Wertsphären, value-spheres (religious, economic, political, aesthetic, erotic, intellectual; see the "Intermediate Reflections," "Zwischenbetrachtung," first published 1915 and collected in his writings on the sociology of religions; Weber 1984) or Lebensordnungen (life orders); this concept refers to an intrinsic logic, or, according to Roth (1992: 457), an "autonomy" emerging from the process of differentiation of these spheres-whose values may enter in conflict-and of its institutions (see also the entry "value-spheres" in Swedberg \& Agevall 2016). Another source for field theory, Ernst Cassirer's theory of symbolic forms - language, science, religion, myths, arts-also postulates their autonomy and partial incompatibility, which renders them irreducible to logics (he speaks, for instance, of the "conceptual world" -Begriffswelt- of physics as "entirely self-contained"; Cassirer 1953: 26).

Bourdieu's reflection on autonomy arose from a methodological question: can cultural domains be autonomized as objects of study? To him, this was only possible under the condition of studying the historical process of autonomization of these spaces of activity (whether the literary, artistic, or scientific field, etc.): "Obviously this approach can only be justified in so far as the object to which it is applied, that is the intellectual field (and thus the cultural field) possesses the relative autonomy which authorizes the methodological autonomization operated by the structural method when it treats the intellectual field as a system which is governed by its own laws," he wrote in his very first article on the subject, "Intellectual Field and Creative Project" (Bourdieu 1969: 89). While the structure of the field may vary "according to the 
varie « selon les sociétés ou selon les époques », « il n’en reste pas moins que certains rapports sociaux fondamentaux se retrouvent dès qu'il existe une société intellectuelle dotée d'une autonomie relative à l'égard des pouvoirs politique, économique et religieux 》 : rapports entre les créateurs et le public, et avec les « instances de légitimation » (Bourdieu 1966 : 892). Bourdieu reniera par la suite cet article qu'il juge trop interactionniste, au profit d'une approche topologique plus objectiviste ; force est cependant de constater que cette première réflexion contient déjà en germe les prémices de la théorie du champ : autonomie relative, se traduisant par un « effet de réfraction » que la structure du champ exerce sur les déterminations externes, instances spécifiques de légitimation et de transmission (il n'est pas encore question de « reproduction »). L'effet de réfraction se manifeste par exemple dans le « rapport qu'un intellectuel exerce avec sa classe sociale d'origine ou d'appartenance, et qui se trouve « médiatisé par la position qu'il occupe dans le champ intellectuel [...]. Ainsi, les déterminismes ne deviennent détermination spécifiquement intellectuelle qu'en se réinterprétant, selon la logique spécifique du champ intellectuel, dans un projet créateur », lequel « fait subir [aux événements économiques et sociaux] une conversion de sens et de valeur en les transmuant en objets de réflexion » (Bourdieu 1966 : 903-904). Alors que, pour Goldman, le véritable sujet de l'œuvre est le groupe d'appartenance du créateur, pour Bourdieu c'est le champ

(Bourdieu 1984 : 212 ; 2001).

Comme il l'explique dans son article de 1971 sur « le marché des biens symboliques », trois conditions sont requises pour qu'un champ se forme : l'émergence d'un groupe de spécialistes de l'activité en question ; l'existence d'instances spécifiques (instances de consécration) ; la formation d'un marché. Bourdieu analyse dans cet article la façon dont ces activités littéraires et artistiques se sont autonomisées du clientélisme et du mécénat grâce au marché, qui a cependant introduit une contrainte nouvelle, society or the age," "it remains true that certain fundamental social relationships are established whenever an intellectual society exists which is relatively independent of the political, economic, and religious authorities," such as the relationships between creators and publics, and with the "granters of legitimacy" (Bourdieu 1969: 109). Bourdieu later dismissed that paper as too interactionist, and adopted a more objectivist topological approach; clearly, however, this early formulation carried the seeds of field theory-with relative autonomy, translating into a 'refraction' effect of the structure of the field over external determinations, and specific authorities of legitimation and transmission ("reproduction" was not used yet). The refraction effect is for instance at work in "the relationship which an intellectual has with the social class he comes from or belongs to [...] mediated by the position he occupies in the intellectual field [...]. Thus, forces of determinism can only become a specifically intellectual determination by being reinterpreted, according to the specific logic of the intellectual field, in a creative project," which obliges economic and social events "to undergo a conversion of meaning and value by transforming them into objects of reflection" (Bourdieu 1969: 118-119). While Goldmann argued that the true subject of an artwork was the group to which the creator belongs, for Bourdieu it is the field (Bourdieu 1984: 212; 2004).

As he showed in his 1971 paper on the "market of symbolic goods" (Engl. ed. 1985c), three conditions must be met for a field to be formed: the emergence of a group of specialists of the activity in question; the existence of specific authorities (instances of consecration); the formation of a market. In that paper, Bourdieu analyses how literary and artistic activities became autonomized from clientelism and patronage through the market, but also shows that the market introduced a new constraint, specific to its 
propre à la logique mercantile. C'est pourquoi Bourdieu décèle le principe d'autonomie dans le refus de la logique marchande, et plus généralement de critères de jugement extra-littéraires (notamment idéologiques et moraux) sur les œuvres. Le primat des critères esthétiques sur tout autre signifie aussi que seul le jugement des pairs est reconnu comme valable, par opposition à la sanction du public telle qu'elle se traduit dans les chiffres de vente. Dans son cours du Collège de France sur Manet, Bourdieu (2013) montrera le rôle du marché dans la conquête de l'autonomie par rapport à l'État qui garantissait le monopole de l'Académie des beaux-arts dans la formation des artistes et l'accès des œuvres à l'espace public (en sélectionnant celles qui seraient exposées au Salon). Le processus d'autonomisation doit donc toujours être rapporté aux contraintes qui s'exercent dans une configuration donnée : en effet, si le marché a permis à ces activités de s'autonomiser face à l'État, l'État permet aujourd'hui de garantir une certaine autonomie face au marché (Sapiro 2003a). Le champ scientifique est un des plus autonomisés, son principal public étant composé de pairs, mais il peut être également soumis à des contraintes politiques, religieuses et économiques selon les conjonctures (Bourdieu 2001).

Par-delà l'étude du processus d'autonomisation face aux pouvoirs politiques, économiques et religieux, qui déterminent les conditions de production et de réception, l'autonomie, toujours relative, signifie que le champ exerce un effet de réfraction variable sur les contraintes extérieures, économiques ou politiques, qui ne cessent pour autant de peser. Comme on l'a vu, c'est à travers la position que les créateurs occupent dans le champ que s'exerce l'effet de réfraction sur les déterminismes sociaux, lesquels se manifestent sous forme de dispositions selon la théorie de l'habitus. Ainsi, contrairement à ce qui est souvent supposé dans les commentaires sur la théorie du champ, le rapport entre habitus et champ n'a rien de mécanique : les dispositions orientent les choix que font own mercantile logic. Hence Bourdieu argues that the principle of autonomy lies in the refusal of the market logic, and more broadly of extra-literary (especially ideological and moral) criteria for judging artworks. The primacy of aesthetic criteria over all others also means that only peer judgment is recognized as valid, as opposed to public sanction translated into sales figures. In his Collège de France lecture on Manet, Bourdieu (2017) evidenced the role of the market in the conquest of autonomy from the state, which ensured the monopoly of the Académie des beaux-arts over the training of artists and the access of artworks to public space (by selecting those exhibited at the Paris Salon). The autonomization process must therefore always be related to the constraints at work in a given configuration: indeed, while the market allowed these activities to gain autonomy from the state, the state now ensures them a degree of autonomy from the market (Sapiro, 2003a). The scientific field is one of the most autonomized, as its main audience is composed of peers, but it may also be subject to contextual political, religious, and economic constraints (Bourdieu 2004).

Beyond the study of the process of autonomization vis-a-vis political, economic, and religious powers that determine the conditions of production and reception, autonomy, which is always relative, means that the field has a variable effect of refraction on external-economic or political-constraints, which are nevertheless always present. As we have seen, this refraction effect on social determinisms, which are manifested in the form of dispositions according to habitus theory, operates through the position occupied by creators in the field. Thus, unlike what is often assumed in comments on field theory, the relationship between habitus and field is by no means a mechanical one: dispositions orient the choices made by cultural producers in a structured "space 
les producteurs culturels dans un « espace des possibles » structuré et se référant à sa propre histoire, lequel constitue le champ. Ces choix et la socialisation dans le champ entraînent une «transsubstantiation » des dispositions éthico-politiques qui les rendent parfois méconnaissables, notamment par le truchement du travail de mise en forme littéraire, artistique ou théorique, ainsi que le montre Bourdieu (1988) dans le cas de Heidegger.

Enfin, Bourdieu (1979) s'est interrogé sur les conditions sociales du jugement esthétique, défini par Kant comme jugement subjectif, sans concept, et désintéressé. Cette pureté du jugement esthétique, son autonomie, occulte les conditions « impures » de production d'un tel jugement, à savoir les conditions sociales et l'effet de distinction qu'il produit dans l'affirmation de la supériorité des classes dotées en capital culturel. Par ailleurs, les usages des productions culturelles et scientifiques sont loin de se limiter aux appropriations désintéressées, fondées sur un jugement autonome par rapport à des critères socio-politiques ou économiques.

\section{Articulations possibles de ces définitions}

Si ces approches et usages du concept d'autonomie sont en bonne partie incompatibles, on peut néanmoins tenter de les articuler. Les théories sociologiques, qu'il s'agisse de la sociologie des professions ou dela théorie des champs, prennent pourpoint de départl'émergence de corps de spécialistes habilités à rendre des jugements compétents dans certains domaines. Leur point de rencontre tient dans l'autorité sociale que ceux-ci acquièrent, condition de l'autonomisation de leur activité, et dans la coupure qu'elle instaure avec les profanes (2.1) La théorie marxiste aborde les productions culturelles dans leurs rapports avec le monde social, comme reflet, expression d'une vision du monde ou idéologie ; Bourdieu introduit la médiation du champ pour penser ces rapports (2.2) of possibles" with a sense of its own history, which constitutes the field. These choices and socialization in the field lead to a "transubstantiation" of ethical and political dispositions, sometimes making them unrecognizable, especially through the process of the imposition of literary, artistic, or theoretical form, as Bourdieu

(1991) shows in the case of Heidegger.

Lastly, Bourdieu (1979) examined the social conditions of aesthetic judgment, defined by Kant as subjective, devoid of concept and disinterested. This view of the purity and autonomy of aesthetic judgment neglects the "impure" conditions of production of judgment-namely, its social conditions and the distinction effect it produces by asserting the superiority of the classes most endowed with cultural capital. Also, the uses of cultural and scientific productions are far from limited to disinterested appropriations, based on a judgment that is autonomous from socio-political and economic concerns.

\section{Possible Linkages Between These Definitions}

While these approaches and uses of the concept of autonomy are to a large extent incompatible, attempts at linking them can nevertheless be proposed. Sociological theories, be they the sociology of professions or field theory, take as a starting point the emergence of groups of specialists who are entitled to give informed judgments in certain domains. They concur in showing the social authority that these specialists acquire, and in demonstrating it to be a condition of the autonomization of their activity and the gap this creates between them and laypeople (2.1). Marxist theory addresses cultural productions in their relations with the social world, as a reflection, an expression of a world vision or ideology; Bourdieu introduces the mediation of the field to conceive these relations (2.2). 


\subsection{Les conditions sociales de l'autonomie du jugement des} spécialistes

La sociologie des professions, supposant l'autonomie des jugements de spécialistes garantie par l'État, a mis l'accent sur l'organisation interne des activités spécialisées, à savoir le contrôle de l'accès au corps, la socialisation par la formation, la déontologie, la discipline intérieure (voir par exemple Goode 1957 ; Abbott 1988 ; Freidson 2001). La théorie des champs s'est centrée de son côté sur l'autonomie par rapport à la demande idéologique et économique, garantie par le jugement des pairs sur les œuvres (Bourdieu 1992 ; Sapiro 2003a). Ces approches ont néanmoins en commun de fonder le principe de l'autonomie sur une éthique de désintéressement et de responsabilité dont il s'agit d'assurer les conditions.

L'avantage de la théorie des champs est qu'elle permet de rendre compte de l'hétérogénéité des groupes professionnels. Cette hétérogénéité, largement constatée par la sociologie des professions (Smith 1958 ; voir la synthèse de Champy 2012 : 95-142), qu'il s'agisse du recrutement social, des conditions d'exercice du métier, ou des formes de spécialisation, n'a pas été théorisée en tant que telle, excepté pour ce dernier aspect (Abbott 1988 : 100-106 et 126 ; pour une articulation de la question de la spécialisation avec la théorie des champs, voir Pinell 2005). De même, comme le pointaient Bucher et Strauss dès leur article de 1961, en insistant sur les principes de cohésion, l'approche structuralo-fonctionnaliste a négligé les conflits internes aux professions, que ne prend pas vraiment en compte non plus l'approche en termes de «mondes » (Becker 1980), laquelle met l'accent sur la division du travail et la coopération. Or la théorie des champs cherche à identifier, de façon relationnelle, les principes d'opposition structurale qui régissent l'activité et la compétition spécifique, notamment entre les établis qui ont le monopole de la définition de l'activité (les « dominants») et les nouveaux entrants qui contestent cette définition ou d'autres groupes occupant des positions dominées (Bourdieu 1984, 1992).

\subsection{The Social Conditions of the Autonomy of Specialist Judgement}

Assuming the autonomy of specialist judgements to be guaranteed by the state, the sociology of professions has emphasized the internal organization of specialized activities-i.e., control over access to the group, socialization through training, professional ethics, and internal discipline (see for instance Goode 1957; Abbott 1988; Freidson 2001). Field theory, on the other hand, has focused on autonomy vis-a-vis ideological and economic demands, guaranteed by peer judgment of the works (Bourdieu 1996; Sapiro 2003a). These approaches all base the principle of autonomy on an ethic of disinterestedness and responsibility, whose conditions must be ensured.

Field theory has the advantage of allowing us to account for the heterogeneity of professional groups. Largely observed in literature on the sociology of professions (Smith 1958; for a synthesis, see Champy 2012: 95-142), this heterogeneity, in terms of social recruitment, working conditions, or forms of specialization, has not been theorized as such, except with respect to specialization (Abbott 1988: 100-106 and 126; for an analysis of specialization drawing on field theory, see Pinell 2005). Likewise, as Bucher and Strauss pointed out in their 1961 article, by emphasizing cohesion, the structural-functionalist approach neglected internal conflicts within professions. Conflicts were also neither genuinely considered in the approach in terms of "worlds" (Becker 1980), which stresses the division of labour and cooperation. Field theory seeks to identify structural principles of opposition governing a specific activity and competition in a relational way, especially between the most established, who hold a monopoly over the definition of the activity (the "dominant") and the newcomers who challenge that definition or other groups occupying dominated positions (Bourdieu 1984; 1996). 
L'autonomie relative est ici un précepte méthodologique invitant à rapporter les enjeux internes des luttes plus ou moins ouvertes à ces oppositions structurales, par lesquelles les enjeux socio-économiques et politiques extérieurs sont plus ou moins retraduits ou « réfractés 》: le degré de médiation indique le degré de cette autonomie. Elle est moindre, par exemple, dans les régimes autoritaires ou dans les situations de crise, où les clivages internes sont déterminés par le rapport au pouvoir (Sapiro 1999 ; Dragomir 2007 ; Leperlier 2018).

Ces enjeux se réfractent aussi de façon spécifique dans les souschamps que forment les spécialités, les disciplines ou les genres (littéraires, musicaux, etc.). Dans la sociologie des professions, la notion de « segment » a été proposée par Bucher et Strauss (1961) pour rendre compte de ces subdivisions et des tensions qu'elles soulèvent, y compris les clivages méthodologiques, tensions et luttes pouvant entraîner un changement (par exemple dans les méthodes ou la déontologie). Cependant, le concept de champ systématise l'approche relationnelle comme sous-tendant la dynamique de concurrence entre inter- ou intra-segments pour l'accumulation du capital symbolique spécifique (ou la construction des réputations), tout en permettant de prendre en compte des activités moins organisées comme les champs de production culturelle. La notion de sous-champ a aussi l'avantage, par rapport à celle, fonctionnaliste et statique, de segment, de réfléchir à la façon spécifique et dynamique dont s'y répercutent les oppositions structurantes du champ.

Ces divisions internes sont masquées par les instances professionnelles qui visent à unifier la profession pour en défendre les intérêts face à l'extérieur (Smith 1958), et qui tendent donc à fonctionner comme des " corps " (Bourdieu 1985). S'appuyant sur le livre d'Ernst Kantorowicz, Les Deux Corps du roi, Bourdieu renvoie à la réflexion des canonistes médiévaux (les théologiens du droit de l'Église) sur la notion de corporatio, que l'on traduit
Here relative autonomy is a methodological principle that calls for relating the internal stakes of struggles of varying openness to these structural oppositions, through which external socioeconomic and political stakes are retranslated and "refracted": the degree of mediation indicates the degree of this autonomy. It is, for instance, lower in authoritarian regimes or crisis situations, where internal cleavages are determined by the relationship to power (Sapiro 1999; Dragomir 2007; Leperlier 2018).

These stakes are also refracted in specific ways in the sub-fields formed by specialties, disciplines and genres (literary, musical, etc.). In the sociology of professions, the concept of "segment" was proposed by Bucher and Strauss (1961) to describe these subdivisions and the tensions they elicit, including methodological cleavages and struggles that may lead to change (for instance in methods or professional ethics). However, the field concept systematizes the relational approach shown to be underlying the dynamic of competition between inter- or intra-segments over the accumulation of specific symbolic capital (or the construction of reputations), while accounting for less organized activities, such as fields of cultural production. Compared with the functionalist and static concept of segment, sub-field also has the advantage of reflecting on the specific and dynamic way in which it echoes the field's structural oppositions.

These internal divisions are concealed by professional bodies which aim to unify the profession to defend its interests vis-à-vis the outside (Smith 1958), and which tend to operate as "corps" (Bourdieu 1985a). Drawing on Ernst Kantorowicz's The King's Two Bodies, Bourdieu harkened back to the reflection of medieval canonists (theologians in Church law) on the concept of corporatio, which also translates as universitas. A "corps" or "corporation" 
aussi par le terme d'universitas. On entend ainsi par « corps » ou " corporation » une entité constituée qui survit à ses membres, sur le plan juridique ou symbolique (Kantorowicz 1957 : 200 sq.), ici le groupe professionnel, lié par une activité commune qui engendre une plus ou moins grande solidarité d'intérêts autour de droits ou de privilèges obtenus ou revendiqués par le groupe en tant qu'entité : le plus ou moins grand succès du groupe à identifier la défense de ces intérêts au bien de la société dans son ensemble - donc à universaliser ses intérêts particuliers - le prémunit contre ou au contraire l'expose aux accusations de " corporatisme ", c'est-à-dire de repli sur des intérêts particuliers au mépris de l'intérêt général ou des causes universelles. Selon Bourdieu (1999a : 11), « il y a corps lorsque un ensemble d'individus est relativement homogène, du point de vue des principes de différenciation dominants dans l'univers social considéré, et uni par une solidarité fondée sur la participation en commun au même capital symbolique ».

Quand une instance atteint un haut degré de monopole dans un champ, au point de pouvoir insuffler un " esprit de corps", on parlera de « corps » plutôt que de « champ » : la clôture du recrutement par concours, numerus clausus, etc., est une modalité de contrôle de l'accès au champ qui est susceptible de conduire à sa transformation en corps, à l'instar du cas des philosophes professionnels sous la Troisième République (Fabiani 1988). Les professions organisées sont celles qui obéissent le plus à ces logiques de corps, alors que dans les moins organisées, les logiques de champ sont plus visibles à travers les luttes internes (Sapiro 2003b). Les « effets de champ » qu'elles produisent opposent des résistances aux entreprises d'unification de la profession comme corps, ainsi qu'on l'a montré à partir du cas des écrivains (Sapiro 2003c ; Sapiro \& Gobille 2006). is in that sense an established entity that survives its members, in legal and symbolic terms (Kantorowicz 1957: 200 sq.)-here, the professional group, bound by a shared activity that fosters to varying extents a solidarity of interests revolving around rights or privileges secured or claimed by the group as an entity: the group's degree of success in identifying the defence of these interests to the good of society as a whole-and by extension in universalizing its own interests-preserves it from or exposes it to accusations of "corporatism," in the sense of focusing on one's own interests at the expense of the general interest or universal causes. According to Bourdieu (1999a: 11), "[...] a corps exists when a group of individuals is relatively homogeneous in terms of the dominant principles of differentiation in the social universe under consideration, and united by a solidarity based on shared participation in the same symbolic capital."

When an authority reaches a high degree of monopoly over a field, to the extent that it can instil an "esprit de corps," the term "corps" is used instead of "field": the closing off of recruitment using competitions, a numerus clausus, etc., is a means of controlling access to the field that may lead to its transformation into a corps, as in the case of the professional philosophers under the Third Republic (Fabiani 1988). Organized professions are those that most operate as corps, whereas in the less organized ones, field logics are more visible through internal struggles (Sapiro 2003b). The "field effects" they produce yield forms of resistance against attempts to unify the profession as a corps, as I have documented in my research on writers (Sapiro 2003c; Sapiro \& Gobille 2006). 
Les différentes approches sociologiques font aussi le constat de la coupure entre spécialistes et profanes, que cette coupure soit considérée comme légitime (selon une perspective wébérienne ou mertonienne) ou critiquée (d'un point de vue marxiste et/ou de celui des Cultural Studies). Or la notion de désintéressement a souvent servi à justifier cette coupure (Parsons 1939), tandis que celle de responsabilité définit le rapport entre spécialistes et profanes (Johnson 1970 : 57). Ces notions ont d'ailleurs circulé entre les professions intellectuelles, qui ont construit leur autonomie en référence et en concurrence les unes par rapport aux autres (Sapiro 2017 ; sur l'éthique de désintéressement dont se réclament les juristes au XVIII ${ }^{e}$ siècle, voir Karpik 1991 : 89-91, 158).

Par-delà la dimension technique ou experte concernant le contrôle des contenus ${ }^{7}$, sur laquelle la sociologie des professions et la théorie des champs convergent - mais aussi l'espace des possibles qui soustend ces contenus, selon la théorie du champ -, la problématique de l'autonomie pose donc une triple question : celle du rapport de l'activité concernée aux contraintes extérieures ; celle des conditions organisationnelles qui la garantissent ; celle de la déontologie, ou éthique de désintéressement dans la pratique professionnelle.

C'est dans le rapport aux contraintes extérieures que l'on constate des points de divergence. Reproduisant l'idéologie professionnelle, la sociologie des professions a longtemps passé sous silence le service de l'État et des intérêts des classes dominantes qui était la contrepartie de l'autonomie statutaire. Cependant, les travaux de Freidson, Larson et bien d'autres ont largement remédié à ce

7. À quoi il faut ajouter la marge d'interprétation et de hiérarchisation des fins laissée aux professionnels, comme le suggère Florent Champy, qui pose aussi la question de savoir s'il s'agit d'une autonomie de réflexion ou de décision (Champy 2012 : 191-230).
Various sociological approaches have also observed the divide between specialists and laypeople, sometimes considering it as legitimate (from a Weberian or Mertonian perspective) and sometimes criticising it (from a Marxist or Cultural Studies perspective). The concept of disinterestedness has often been used to justify this divide (Parsons 1939), whereas that of responsibility defines the relationship between specialists and laypeople (Johnson 1970: 57). These concepts have circulated between the intellectual professions, who constructed their autonomy by referring to one another and competing with one another (Sapiro 2017; on the ethic of disinterestedness professed by eighteenthcentury lawyers, see Karpik 1991: 89-91 and 158).

Beyond the technical and expert dimensions concerning the control of contents ${ }^{7}-\mathrm{a}$ point of convergence between the sociology of professions and field theory-as well as the space of possibles underlying these contents, according to field theory-the issue of autonomy raises a triple question: that of the relationship of the activity concerned to external constraints; that of the organizational conditions that ensure it; and that of the ethics of disinterestedness in professional practice.

Points of divergence are observed where the relationship to external constraints is concerned. Reproducing the professional ideology, for a long time, the sociology of professions neglected to address the quid pro quo of statutory autonomy-namely, the service of the state and of the interests of the ruling classes. However, writings by Freidson, Larson, and many others have largely filled this gap

7. As well as the margin of interpretation and hierarchization of ends left to the professionals, as suggested by Florent Champy, who also raises the question of whether this is an autonomy of reflection or decision (Champy 2012: 191-230) 
problème en analysant l'autonomie comme une revendication des professionnels et pas comme une essence de leur activité.

D'après Terence Johnson (1970: 41-43), la spécialisation crée un système d'interdépendance qui ouvre des " potentialités pour l'autonomie », par la « structure d'incertitude », ou « indétermination » des rapports entre producteurs et consommateurs, incertitude que les institutions viennent réduire. En fonction du rapport de force, cette incertitude sera réduite au profit du producteur ou du consommateur. Le modèle d'analyse qu'il propose permet de prendre en compte des formes différentes de relations entre producteurs et consommateurs, selon qu'elles sont déterminées par les premiers (professionnalisme), par les seconds (mécénat ou grosses entreprises ayant le quasi-monopole de la commande de certains services), ou par un tiers (État ou entrepreneurs). L'autonomie des producteurs est élevée dans le premier cas, faible dans le second, négociée dans le troisième. Ces trois formes de relations impliquent différents niveaux d'indétermination du rapport entre l'offre et la demande, et donc d'incertitude, selon Johnson (1970:41-43)

Les conditions organisationnelles qui garantissent l'autonomie technique ont été bien étudiées par la sociologie des professions, en particulier le rôle des associations (Millerson 1998 [1964]). Cependant, le lien présupposé entre instances professionnelles et autonomie, même technique, est remis en cause par les travaux empiriques sur des régimes autoritaires, comme celui de Jarausch (1990) sur les ingénieurs et les enseignants sous le nazisme, ou ceux sur le rôle des unions d'écrivains (Garrard \& Garrard 1990 ; Dragomir 2007 ; cette idée est développée dans Sapiro 2003a). En effet, même si les professionnels ont pu négocier ou obtenir le maintien d'un statut particulier dans ces régimes, l'autonomie technique est restreinte de fait par la censure idéologique qui s'exerce sur les producteurs intellectuels. Les concepts d'autonomie by analysing autonomy as a demand by professionals, not as an essence of their activity.

According to Terence Johnson (1970: 41-43), specialization creates a system of interdependence that offers "potentialities for autonomy," through the "structure of uncertainty" or "indeterminacy" in the relationship between producer and consumer-this uncertainty is reduced by the institutions. Depending on the balance of power at work, uncertainty is reduced to the producer's or the consumer's benefit. Johnson's analytical model accommodates different forms of relationship between producer and consumer, determined either by the former (professionalism), the latter (patronage; corporations with a virtual monopoly over some services) or a third party (the state or entrepreneurs). The producers' autonomy is high in the first case, weak in the second, and negotiated in the third. These three forms of relationship imply different levels of indeterminacy in the relationship between supply and demand, and by extension different levels of uncertainty, according to Johnson (1970: 41-43).

The organizational conditions ensuring technical autonomy have been extensively studied in the sociology of professions-especially the role of associations (Millerson 1998 [1964]). However, the supposed link between professional bodies and autonomyeven technical-has been challenged by empirical research on authoritarian regimes, such as Jarausch's (1990) study on engineers and teachers under Nazism, and work on the role of writers' unions (Garrard \& Garrard 1990; Dragomir 2007; I expand on this in Sapiro 2003a). Indeed, even though professionals were able to negotiate or retain a distinct status under these regimes, their technical autonomy was in effect restricted by the ideological censorship imposed on intellectual professions. The concepts of autonomy and heteronomy, as Bourdieu defined them, offer a heuristic framework to approach 
et d'hétéronomie tels que définis par Bourdieu offrent un cadre heuristique pour appréhender ces rapports plus ou moins ambigus entre les instances professionnelles et les pouvoirs en place. II en va de même pour les instances de consécration, négligées par la sociologie des professions, et plus étudiées par la théorie des champs, mais dont le rôle dans le maintien de l'autonomie peut être tout aussi ambigu comme on l'a montré pour l'Académie française et l'académie Goncourt sous le régime de Vichy ; paradoxalement, c'est une instance clandestine mise en place par le Parti communiste, le Comité national des écrivains, qui a défendu les principes de l'autonomie littéraire dans cette conjoncture de crise (Sapiro 1999). Comme le soulignait Alain Viala (1990), les institutions de la vie littéraire jouent un rôle charnière entre le champ et les pouvoirs, et leur fonctionnement ainsi que leur rôle doivent faire l'objet d'études empiriques concrètes avant de déterminer le type d'autonomie (ou

d'hétéronomie) qu'elles garantissent.

Concernant la déontologie, il est nécessaire, sur le plan méthodologique, de distinguer le discours sur l'autonomie de la pratique, laquelle peut contredire le discours. Ceci vaut aussi bien pour la sociologie des professions, où l'on a pu constater des pratiques consistant à faire passer les intérêts du professionnel avant ceux du client, contrairement au code de l'éthique professionnelle (Freidson 1970 : 360-362), que pour la théorie des champs : ainsi, par exemple, sous l'occupation allemande, La Nouvelle Revue française, relancée à l'instigation de l'ambassadeur d'Allemagne Otto Abetz, affichait un discours sur l'autonomie de l'art qui devait se maintenir en tout circonstances, alors même qu'étaient exclus de la revue d'anciens collaborateurs pour des raisons qui n'avaient rien à voir avec l'art, à savoir leurs origines religieuses (juives) ou leurs opinions politiques

(communistes et antinazis) (Sapiro 1999 : 402-408). these more or less ambiguous relationships between professional bodies and the political, religious, or economic authorities in place. This also applies to instances of consecration, which have been neglected in the sociology of professions, and subject to more attention in field theory, but whose role in ensuring continued autonomy can be just as ambiguous, as I have shown in the cases of the Académie française and the Académie Goncourt under the Vichy regime in France; paradoxically, a clandestine organization set up by the Communist Party, the Comite national des écrivains [National committee of writers], stepped up to defend the principles of literary autonomy during these years of crisis (Sapiro 1999). As Alain Viala (1990) noted, the institutions of literary life are crucial links between the field and the political and economic authorities, and their functioning and role must be subject to concrete empirical studies to establish the type of autonomy (or heteronomy) that they ensure.

Regarding ethics, it is methodologically necessary to distinguish between the discourse on autonomy and actual practice, which may contradict discourse. This goes equally for the sociology of professions, which has observed practices wherein the professional's interests take precedence over the client's, in breach of the code of professional ethics (Freidson 1970: 360-362), and field theory: for instance, under the German occupation of France, the Nouvelle revue française, a literary magazine whose publication had resumed on the initiative of German ambassador Otto Abetz, ostensibly conveyed a discourse on ensuring the autonomy of art under any circumstances even though at the very same time former contributors were being excluded for reasons entirely unrelated to art, specifically their (Jewish) religious background or their (communist and antiNazi) political opinions (Sapiro 1999: 402-408). 


\subsection{L'autonomie relative des œuvres}

Les usages marxistes du concept d'autonomie mettent l'accent sur l'autonomie relative des œuvres par rapport aux conditions sociales dans lesquelles elles ont été produites. Cette idée peut se rapprocher de celle d'autonomie technique, mais pose comme pour cette dernière la question des conditions qui la rendent possible.

II manque, on l'a vu, à ces approches marxistes centrées sur les œuvres l'idée de la médiation qu'exercent leurs conditions de production et de circulation. On la trouve dans une autre tradition marxiste, celle qui va de Gramsci aux fondateurs des Cultural Studies, notamment Raymond Williams (1981). Celuici n'emploie pas le terme d'autonomie en ce sens mais son programme de recherche sur les institutions de la vie littéraire - éditeurs, revues, académies, cercles - comportait ces aspects (il se réfère à Bourdieu). Ajoutons que la thèse de Goldmann sur la vision du monde janséniste de la noblesse de robe dans le cas de Racine n'est pas du tout incompatible avec la théorie du champ. En effet, on ne peut encore vraiment parler d'un champ littéraire autonomisé au $\mathrm{xV} \|^{\mathrm{e}}$ siècle, même si, comme l'a souligné Viala (1985), on voit apparaître un groupe de spécialistes et une instance de consécration, l'Académie française (voir aussi SaintJacques \& Viala 1994). Mais le clientélisme prévaut encore, ce qui conditionne assez fortement la production des œuvres, en l'absence d'un marché des biens symboliques qui n'émergera qu'au siècle suivant. En revanche, Bourdieu reproche à Sartre d'avoir omis la médiation du champ dans sa magistrale biographie de Flaubert, L'ldiot de la famille (1971-1972), qui rapporte l'œuvre à l'histoire familiale et à une analyse de classe sans aborder les conditions de production littéraire à une époque où, comme il le montrera dans Les Règles de l'art (1992), un pôle de production restreinte se forme pour défendre les principes de l'autonomie du jugement des

\subsection{The Relative Autonomy of Artworks}

Marxist uses of the concept of autonomy emphasize the relative autonomy of artworks vis-à-vis the social conditions of their production. This idea bears similarities with that of technical autonomy, but likewise raises the question of its conditions of possibility.

As previously noted, these artwork-centred Marxist approaches lack an examination of the mediation exercised by their conditions of production and circulation. This is found in another strand of Marxist tradition, running from Gramsci to the founders of Cultural Studies, especially Raymond Williams (1981). Williams does not use the term autonomy in that sense, but his research programme on the institutions of literary life-publishers, magazines, academies, and circles-took these aspects into account (he referred to Bourdieu). Also worth noting is that Goldmann's thesis on the Jansenist world vision of the noblesse de robe in his analysis of Racine is in no way incompatible with field theory. There was admittedly no genuinely autonomized literary field in the seventeenth century, even though, as Viala (1985) observed, a group of specialists and an instance of consecration, the Académie française, emerged (see also SaintJacques \& Viala 1994). Yet clientelism still prevailed, and largely conditioned the production of artworks, in the absence of a market of symbolic goods - which would only develop during the following century. On the other hand, Bourdieu faulted Sartre for ignoring the mediation of the field in his masterly biography of Flaubert, The Family Idiot (1971-1972), which relates the writer's oeuvre to his family history and a class analysis without addressing the conditions of literary production at a time when, as Bourdieu went on to show in The Rules of Art (1992 Engl. ed. 1996), a pole of restricted production developed to defend the principles of the autonomy of the judgment of peers and specialists in the face of 
pairs et des spécialistes, face à la logique marchande qui prévaut au pôle de grande production du marché du livre en expansion.

\section{Propositions pour un usage heuristique du concept d'autonomie}

À la lumière de ces possibles articulations, on proposera de distinguer trois niveaux d'autonomie : celui des conditions de production, celui des pratiques, celui de la réception et des usages,

même si ces trois niveaux peuvent se trouver imbriqués.

\subsection{Le degré d'autonomie des conditions de production}

Revenons aux trois configurations de relations entre producteurs et consommateurs distinguées par Johnson. Comme on l'a vu, l'autonomie des producteurs est élevée lorsque ceux-ci sont en mesure de déterminer les relations qu'ils entretiennent avec les consommateurs : c'est le modèle des professions libérales tel qu'il s'est développé aux États-Unis avant de circuler ailleurs. Les professionnels bénéficient d'une autonomie technique élevée, garantie par des instances professionnelles (ordres ou associations dotées de pouvoirs), mais cette autonomie conférée par l'État repose sur le degré de libéralisme du régime (dans les régimes autoritaires, les ordres professionnels ou les associations professionnelles sont encadrés et contrôlés par le pouvoir) et n'est jamais complète (comme l'a fait remarquer Freidson [2001], la formation qui conditionne l'accès à la profession en question n'est pas assurée par ces instances mais par des établissements dont les diplômes sont accrédités par l'État).

Qui plus est, il faut interroger le prix de cette autonomie technique en termes de service rendu en retour au pouvoir en place, ce qui pose la question, soulevée par Merton et par Bourdieu, de l'autonomie par rapport à l'idéologie dominante et à la demande étatique. Les the market-oriented approach that prevailed at the pole of largescale production of the expanding book market.

\section{Proposals for a Heuristic use of the Concept of Autonomy}

In light of these possible connections, I propose a distinction between three, sometimes embedded, levels of autonomyconditions of production, practices, reception and uses.

\subsection{The Degree of Autonomy of Conditions of Production}

Let us come back to the three forms of relationship between producer and consumer singled out by Johnson. As previously mentioned, the producers' degree of autonomy is high when they are in a position to determine their relationships with consumers, as in the model of independent professions that developed in the US before circulating across the world. Professionals enjoy a high degree of technical autonomy, guaranteed by professional bodies (ordres or associations endowed with powers), but this statesanctioned autonomy depends on the regime's degree of liberalism (in authoritarian regimes, professional bodies are supervised and kept in check by the authorities) and is never complete (as Freidson [2001] observed, the training that conditions access to the profession in question is not offered by these professional bodies,

but by institutions whose diplomas are accredited by the state).

Additionally, the price of this technical autonomy in terms of the service rendered to the political authorities in return also deserves consideration. This raises the question, investigated by Merton and Bourdieu, of autonomy vis-à-vis the dominant ideology and 
professions organisées peuvent être conçues comme des champs fortement centralisés autour d'instances professionnelles qui, selon une logique de " corps ", contrôlent l'accès et les règles du jeu, et ont le pouvoir de sanctionner les « hérétiques » qui dérogent à l'orthodoxie. Ce contrôle destiné en principe à garantir l'intérêt des clients est susceptible d'être détourné au profit des intérêts du pouvoir (comme on l'a vu avec les médecins hygiénistes au XVIII siècle), des grandes entreprises (les avocats, les ingénieurs ou les scientifiques travaillant pour elles mettent souvent leur autonomie technique au service d'intérêts financiers ; sur le cas des économistes travaillant pour les banques, voir Lebaron 2000), des classes dominantes, ou de certains groupes ethniques ou religieux dominants. Le numerus clausus imposé aux médecins et avocats juifs en Europe de l'Est dans l'entre-deux-guerres, ou le délai de dix ans imposé aux médecins étrangers en France dans les années 1930 pour être autorisés à exercer, visait ainsi à limiter les conditions de la concurrence pour les professionnels issus du groupe ethnique ou national dominant. II en va de même de l'exclusion des femmes de ces professions (Rennes 2007). Ces pratiques révèlent des formes d'hétéronomie des professionnels par rapport à différentes composantes du champ du pouvoir, lorsqu'ils sont en position de réguler les rapports avec les clients. Les instances professionnelles constituent un site d'observation des négociations avec ces différentes composantes et donc des traductions de ces formes d'hétéronomie en règles et en pratiques professionnelles, mais l'opposition entre autonomie et hétéronomie est, avec celle entre dominants et dominés (selon le volume du capital spécifique), un principe de structuration des champs et donc une grille pour analyser les pratiques elles-mêmes.

Lorsque les clients des services ou des produits sont principalement des mécènes, comme pour les arts sous l'Ancien Régime en France, ou de grosses entreprises ayant le quasi-monopole de state demand. Organized professions may be conceived as highly centralized fields, around professional bodies that operate with a logic of "corps," in that they control access to the game and its rules, and have the power to punish the 'heretics' that stray from orthodoxy. While this control is in principle aimed at ensuring that the clients' interests are safeguarded, it is liable to being hijacked for the benefit of the authorities (as in the case of eighteenth-century hygienist physicians), corporations (the lawyers, engineers, and scientists working for them often use their technical autonomy to serve financial interests; on the case of economists working for banks, see Lebaron 2000), the dominant classes, or dominant ethnic or religious groups. Provisions such as the numerus clausus for Jewish doctors and lawyers in interwar Eastern Europe and the ten-year wait for foreign doctors in 1930s France were for instance aimed at restricting competition for professionals belonging to the dominant ethnic or national group. The same applies to the exclusion of women from these professions (Rennes 2007). These practices reveal forms of heteronomy of professionals vis-à-vis various components of the field of power, when they are in a position to regulate relationships with clients. Professional bodies are a site of observation of negotiations with these components, and hence of translations of these forms of heteronomy into professional rules and practices. However, the opposition between autonomy and heteronomy is, alongside that between dominant and dominated (according to the volume of specific capital), a structuring principle of fields and therefore a grid for analysing the practices themselves.

When the clients of services or products are mainly patrons, as in the arts during the French Ancien Régime, or corporations with a virtual monopoly over orders, as in the case of consulting engineers 
la commande, comme pour les ingénieurs-conseils (Henry 1992, 2012), l'autonomie des professionnels est faible puisque leur production est fortement dépendante de la demande. Dans ce cas, la production est déjà aussi largement déterminée par la réception et les usages qui peuvent être faits des productions symboliques.

Même si Johnson ne les mentionne pas, la configuration dans laquelle l'autonomie des producteurs est négociée par la médiation d'un tiers (État ou entrepreneurs) correspond très bien aux marchés de l'art, avec d'un côté les aides étatiques, de l'autre le rôle des intermédiaires (éditeurs, agents littéraires, galeristes, sociétés de production de film et de musique). Dans des États autoritaires, comme dans les régimes communistes et fascistes, l'autonomie des producteurs culturels est faible bien que ceuxci soient souvent très professionnalisés, et les organisations professionnelles servent d'instance de contrôle idéologique, comme on l'a dit. Dans les économies de marché, leur autonomie est affaiblie par la dépendance à la logique de profit qui motive nombre d'entrepreneurs culturels - agents « doubles » tenus de plus ou moins la concilier avec les logiques spécifiques aux univers culturels (Bourdieu 1977) -, soumettant la production à la logique de marché. Les travaux empiriques sur les évolutions récentes du champ éditorial en France et dans le monde angloétats-unien ont révélé le poids accru de ces contraintes d'ordre économique (Bourdieu 1999b ; Thompson 2005). D'où la structure duale identifiée par Bourdieu entre un pôle de grande production et un pôle de production restreinte, qui caractérise tous les marchés de biens symboliques. Par rapport à ces contraintes économiques, l'État peut avoir un rôle correctif en allouant des aides à une partie de la production pour laquelle la demande est plus réduite, mais dont la valeur est estimée élevée par les spécialistes auxquels est délégué le travail d'évaluation, forme de reconnaissance de l'autonomie de leur jugement (Sapiro 2003a).
(Henry 1992; 2012), the autonomy of professionals is weak, as their production is largely dependent on demand. In that case, production is also largely informed by reception and the possible uses of symbolic products.

Although Johnson does not discuss them, the case of third-party mediation (by the state or entrepreneurs), wherein the autonomy of producers is negotiated, very much fits the art markets that are characterized by state subsidies on one hand, and the significant role of intermediaries (publishers, literary agents, gallery owners, and film and music production companies) on the other. In authoritarian states, as in communist and fascist regimes, the autonomy of cultural producers is weak, even though they are highly professionalized, and professional bodies act as ideological control bodies. In market economies, their autonomy is weakened by dependence on a logic of profit that drives many cultural entrepreneurs - "double" agents who are more or less expected to reconcile that logic with the specific logics of cultural worlds (Bourdieu 1977)-and submits production to a market-oriented rationale. Empirical studies on recent trends in the publishing field in France and the Anglo-American world have shown that such economic constraints have a growing impact (Bourdieu 1999b; Thompson 2005). Hence the dual structure identified by Bourdieu, with a pole of large-scale production and one of small-scale production, which characterizes all markets of symbolic goods. In response to these economic constraints, the state may play a corrective role by subsidizing part of the production for which demand is lower, but whose value is estimated to be high by the specialists entrusted with evaluation, in a form of recognition of the autonomy of their judgment (Sapiro 2003a). 
Très utiles pour comprendre le degré et le type d'autonomie du point de vue des conditions de production, ces trois configurations des relations entre producteurs et consommateurs ne suffisent cependant pas entièrement à les déterminer, dans la mesure où il faut les inscrire dans une configuration sociopolitique et économique plus large selon le type de régime et de contrôle idéologique des pratiques, ce qui nous conduit au deuxième niveau.

\subsection{L'autonomie des pratiques}

Si les discours des producteurs sur l'autonomie sont utiles pour déterminer leurs revendications en fonction des conditions de production, il est nécessaire de les confronter aux pratiques, comme

on l'a vu.

Dès l'avènement du marché des biens symboliques au xvIII siècle, certains hommes de lettres, comme Karl Philipp Moritz, inspirateur de Kant, ont mis en garde les producteurs culturels (en particulier les artistes) contre la tentation de flatter le public au détriment des exigences propres à leur art et à leur éthique professionnelle : contre l'idée, défendue par Moses Mendelssohn, que l'unité des arts réside dans leurs effets, à savoir les émotions que produisent les œuvres du fait des relations d'harmonie et de symétrie, Moritz la situe aussi dans cette perfection formelle qui sous-tend le beau idéal mais en insistant sur l'absence de finalité, que Kant théorisera en définissant l'œuvre comme finalité sans fin (Woodmansee 1994). C'est pourquoi les vastes succès de certaines productions culturelles sont suspects d'être le fruit de compromis, voire de compromissions (facilités, démagogie) du producteur pour séduire un public indifférencié et peu familier avec les canons esthétiques. Quand il ne s'agit pas de genres très codifiés comme les films de genre, le roman sentimental ou le polar, certains intermédiaires (éditeurs, agents, producteurs de films ; sur le problème de l'autonomie au cinéma, voir Duval 2016)
While they are highly useful to our understanding of the degree and type of autonomy in terms of conditions of production, these three configurations are not in themselves enough to establish them. Indeed, they must be considered within a broader socio-political and economic context according to the type of regime and the ideological control over practices, which brings us to the second

level.

\subsection{The Autonomy of Practices}

While the producers' discourses on autonomy are useful to establish their demands according to the conditions of production, they need to be confronted with practices.

As soon as the market of symbolic goods emerged in the eighteenth century, some men of letters, such as Karl Philipp Moritz, an influence on Kant, warned cultural producers (particularly artists) of the temptation to flatter the audience to the detriment of the requirements of their art and their professional ethics. At odds with Moses Mendelssohn's idea that the unity of the arts resides in their effects, meaning the emotions produced by artworks as a result of relations of harmony and symmetry, Moritz also finds it in the formal perfection that underpins ideal beauty, but emphasizes the absence of finality, which Kant theorized by defining the artwork as finality without end (Woodmansee 1994). This is why the huge success of some cultural productions is suspected of resulting from the producer's compromises, or dishonourable attempts to seduce an undifferentiated audience, lacking familiarity with the aesthetic canons. Except in highly codified forms such as genre films, romances, or crime stories, some intermediaries (publishers, agents, film producers, etc.; on autonomy in cinema, see Duval 2016) intervene upstream of the creative work to make sure that 
interviennent en amont dans le travail de création pour s'assurer de la rentabilité économique du projet, et font un effort de promotion en aval sur lequel on reviendra dans la prochaine section. La logique de marché peut également influer sur les pratiques scientifiques ou professionnelles qui sont susceptibles de servir des intérêts économiques, comme on l'a vu. Beaucoup de groupes industriels ont des avocats travaillant pour eux. Mais par-delà les pratiques hétéronomes, les produits scientifiques a priori les plus autonomes et abstraits comme l'économie mathématisée peuvent également être instrumentalisées à des fins « impures », telles que la justification de politiques d'austérité (Lebaron 2000)

Les pouvoirs politiques et religieux ont souvent cherché à subordonner les sciences comme les arts et les lettres pour en faire des instruments de propagande : le réalisme socialiste comme méthode de création en est un exemple (Robin 1986, Aron, Matonti, Sapiro 2002 ; sur la science, voir Matonti 2002). Toutefois, même lorsqu'elles se traduisent par l'interdiction et la censure, ces contraintes n'excluent pas des pratiques hétérodoxes, sous forme codée (par exemple la "poésie de contrebande » sous l'occupation allemande en France, ou l'interprétation théâtrale des acteurs polonais sous le régime communiste), clandestine (les samizdat), ou par la délocalisation à

l'étranger (sur ces options, voir Sapiro 2003).

Par-delà ces contraintes, les approches marxistes ont mis au jour, à travers les notions de «vision du monde », d'« idéologie 》 ou d'« hégémonie », les dimensions éthico-politiques des productions culturelles. Comme on l'a vu, Althusser et ses disciples remettent en cause la notion de "vision du monde » privilégiée par Goldmann au profit de celle d'« idéologie », qui restitue la fonction de reproduction qu'exercent ces productions. Raymond Williams lui préfère celle, gramscienne, d'« hégémonie »(Williams 2009). Pierre Bourdieu a forgé quant à lui le concept de «pouvoir symbolique », qui insiste the project will be economically profitable, and subsequently commit to a promotion effort that will be analysed in the next section. The market-oriented rationale may also influence scientific or professional practices, liable to serve economic interests, as previously noted. Many industrial groups have lawyers working for them. Beyond heteronomous practices, the scientific products that may appear to be the most autonomous and abstract, such as mathematized economics, can also be instrumentalized for "impure" purposes, such as justifying austerity policies (Lebaron 2000)

Political and religious authorities have often sought to subdue the sciences as well as the arts and letters to turn them into propaganda instruments; socialist realism as a creative method is an example of this (Robin 1986; Aron, Matonti, Sapiro 2002; on science, see Matonti 2002). However, even when they result in bans and censorship, these constraints do not preclude heterodox practices, in coded form (for instance, "contraband poetry" during the German occupation of France, or the theatrical performances of Polish actors under the communist regime), clandestine form (samizdat), or displaced abroad (on these options, see Sapiro 2003).

Beyond such constraints, Marxist approaches have evidenced the ethical and political dimension of cultural productions using the concepts of "world vision," "ideology," and "hegemony." As previously noted, Althusser and his disciples preferred "ideology," which conveys the function of reproduction exercised by these representations, over Goldmann's "world vision." For his part, Raymond Williams favours the Gramscian term "hegemony" (Williams 2009). Pierre Bourdieu forged the concept of "symbolic power," which stresses the structuring cognitive functions of 
sur les fonctions cognitives structurantes des biens symboliques, dans la tradition néokantienne, tout en rappelant avec Weber et Marx leurs fonctions sociales dans les rapports de domination, fonctions qui s'exercent d'autant mieux qu'elles sont méconnues comme telles (Bourdieu 1977). En effet, qu'elles reproduisent l'idéologie dominante ou la remettent en cause au profit de visions du monde alternatives, les productions culturelles ne sont jamais « neutres » dans la mesure où elles tirent leur signification des relations qu'elles entretiennent avec l'espace des représentations et des formes symboliques existantes à un moment donné, tant du point de vue des conditions de production que de réception. Leur degré d'autonomie tient, selon la théorie des champs, à l'effet de réfraction opéré par le travail de mise en forme, qui s'inscrit dans un espace des possibles historiquement constitué. La reproduction ou le renouvellement de ces formes symboliques est un enjeu dans des univers où l'originalité est la valeur première (ce

que Lucien Karpik [2007] appelle « l'économie des singularités »).

La question est de savoir si cette autonomie formelle - proche de l'autonomie technique de la sociologie des professions - suffit à garantir une autonomie par rapport à l'idéologie dominante ou aux fonctions sociales dévolues aux œuvres d'art. Force est de constater que le travail de mise en forme le plus " autonome " n'empêche pas qu'une œuvre véhicule des schèmes éthicopolitiques associés à tel ou tel groupe ou classe, comme l'a montré Bourdieu (1988) dans le cas de Heidegger. La lecture politique que fait Jeffrey Mehlmann (2003) du "Cimetière marin » du poète français Paul Valéry détecte dans le syntagme « têtes inhabitées » une réminiscence de la formation du poète à la craniométrie auprès du raciologue Vacher de Lapouge, Valéry ayant déterré et mensuré six cents crânes dans un cimetière abandonné. Sans aller jusqu'à faire de Valéry lui-même un penseur raciste, Mehlmann montre comment la vision du monde que véhicule son œuvre est imprégnée de l'idée de la supériorité de l'homme aryen. symbolic goods in the neo-Kantian tradition, while concurring with Weber and Marx in pointing out their social functions in relations of domination, which are all the more effective as they are unrecognized-"méconnues"-as such (Bourdieu 1977). Indeed, whether they reproduce the dominant ideology or challenge it to support alternative worldviews, cultural productions are never "neutral," in that they get their significance from their relations with the space of representations and the symbolic forms that exist at a given juncture, both in terms of conditions of production and reception. According to field theory, their degree of autonomy hinges on the refraction effect resulting from a process of imposition of form - mise en forme-inscribed in a historically constituted space of possibles. The reproduction or renewal of these forms is a major stake in worlds where originality is the most important value (Lucien Karpik [2007] calls this "the economics of singularities").

The question is whether this formal autonomy-which has similarities with technical autonomy in the sociology of professions-is enough to ensure autonomy vis-à-vis the dominant ideology or the social functions given to artworks. Crucially, even the most "autonomous" imposition of form will not prevent a work from conveying ethical and political schemes associated with a given group or class, as Bourdieu (1991) has shown in the case of Heidegger. Jeffrey Mehlmann's (2003) political reading of French poet Paul Valéry's "Graveyard by the Sea" finds in the phrase "derelict heads" a reminiscence of the author's training in craniometry with raciologist Vacher de Lapouge, during which Valéry had dug up and measured 600 skulls in an abandoned cemetery. Without going quite as far as to depict Valéry himself as a racist thinker, Mehlmann shows how the superiority of the Aryan man imbues the worldview conveyed in his work. 
Ainsi le concept d'autonomie renvoie au processus de retraduction des enjeux extra-littéraires selon les logiques spécifiques du champ. La notion de " monologisme » proposée par Bakhtine en opposition à celle de "dialogisme » (hétérogénéité des points de vue, des styles, etc.), et qu'emploie Régine Robin (1986) pour analyser le réalisme socialiste, pose la question des limites de l'autonomie et des dispositions des producteurs culturels et intellectuels à l'hétéronomie.

En revanche, contrairement à ce qui est souvent supposé, la politisation des producteurs de biens symboliques n'est pas contradictoire en soi avec l'autonomie : en effet, les différentes formes que revêtent leur engagement sont généralement liées à leur activité et à leur position dans le champ, leur degré d'autonomie tenant à leur indépendance par rapport à une demande extérieure, en provenance des groupes sociaux ou de leurs porte-parole (organisations politiques) (Sapiro 2009, 2018). Les avant-gardes au $\mathrm{Xx}^{\mathrm{e}}$ siècle ont rêvé de révolutionner le monde par des moyens proprement artistiques (Brun 2014 ; Gobille 2018).

Qui plus est, même les œuvres les plus formelles ou abstraites peuvent servir des objectifs politiques indépendamment des intentions de l'auteur. Tel fut le cas de l'art abstrait, instrumentalisé dans le cadre de la politique étrangère états-unienne pour incarner sa conception du libéralisme dans l'art face au réalisme socialiste figuratif (Guilbaut 2006). Mais cette dimension relève plutôt des usages et appropriations des œuvres, elle répond aussi en partie à la question posée par Marx de l'autonomisation des œuvres par rapport à leurs conditions de production, notamment par le biais du processus de canonisation.

Avant d'en venir à cette dernière question, il faut rappeler la distinction que fait Williams (2009) entre les formes culturelles résiduelles (ayant vu le jour dans une formation sociale antérieure, elles subsistent dans
The concept of autonomy thus relates to the process of translation of extra-literary issues according to logics specific to the field. The term "monologism" proposed by Bakhtin in contrast to "dialogism" (the heterogeneity of points of view, styles, etc.), and employed by Régine Robin (1986) in her analysis of socialist realism, raises the question of the limits of autonomy and dispositions towards heteronomy of cultural and intellectual producers.

Yet despite frequent assumptions, the politicization of producers of symbolic goods is not in itself in contradiction with autonomy: indeed, the different forms of their engagement are generally related to their activity and position in the field. Their degree of autonomy hinges on their independence from outside demands from social groups or their spokespersons (political organizations) (Sapiro 2009, 2018). Twentieth-century avant-gardes dreamed of revolutionizing the world through purely artistic means (Brun 2014; Gobille 2018).

In addition, even the most formal and abstract works may serve political goals regardless of the author's intentions. This happened to abstract art, which was instrumentalized by US foreign policy to embody the American conception of liberalism in art in contrast to figurative socialist realism (Guilbaut 2006). However, this aspect rather pertains to the uses and appropriations of artworks, which also partly addresses Marx's question as to the autonomy of works vis-à-vis their conditions of production, particularly through the canonization process.

Before we move on to this last question, it is worth recalling Williams's (2009) distinction between residual cultural forms (having emerged in a previous social formation, they linger in 
la conjoncture actuelle tout en étant marginales par rapport à la culture dominante) et les formes culturelles émergentes, parmi lesquelles il différencie alternatives et oppositionnelles. On pourrait suggérer de croiser ces distinctions (qui nous semblent plus heuristiques que la simple bipartition proposée par Mannheim entre idéologie et utopie), avec l'examen de la nature plus ou moins autonome ou hétéronome des pratiques (autoréférentialité, inscription dans l'histoire du champ, capacité à renouveler les formes, autonomie du projet par rapport à une demande préformatée, etc.). La notion de forme symbolique permettrait d'articuler les aspects formels avec les schèmes de perception et d'évaluation véhiculés par les œuvres.

\subsection{L'autonomie du jugement critique ou technique}

L'autonomie technique repose sur l'évaluation par les pairs, aussi bien dans la sociologie des professions que dans la théorie des champs. Si elle n'est pas en mesure d'empêcher les appropriations et usages idéologiques des productions ou des services, elle peut leur opposer ses propres critères de jugement, centrés sur les aspects « techniques » qui requièrent une connaissance spécialisée, qu'il s'agisse de la science, des pratiques professionnelles ou des productions artistiques.

Selon la logique de marché, c'est la rentabilité mesurée aux chiffres de vente pour les œuvres ou d'usages pour les services qui introduit des principes hétéronomes susceptibles de nuire à la qualité des produits, en ce qu'ils conduisent à faire des compromis pour flatter le goût d'un public de profanes. Ici il faut distinguer effectivement les trois configurations définies par Johnson. Dans le cas du professionnalisme, l'argument de l'autonomie peut être détourné au profit des intérêts des professionnels contre ceux des clients, comme on l'a vu, ces derniers étant assez démunis face à l'autorité des spécialistes. Le cas de la dépendance forte the present juncture, but on the fringes of dominant culture), and emergent cultural forms, which include alternative and oppositional forms. It might be worth cross-examining these distinctions (which I contend are more heuristic than the binary ideology/utopia division proposed by Mannheim) and the degrees of autonomy or heteronomy of practices (self-referentiality, inscription in the history of the field, ability to renew forms, autonomy of the project from a pre-formatted demand, etc.). The concept of symbolic form could allow us to link formal aspects with the perception and evaluation schemes conveyed by the works.

\subsection{The Autonomy of Critical or Technical Judgment}

Technical autonomy is based on peer evaluation in both the sociology of professions and field theory. While it cannot prevent ideological appropriations and usages of productions and services, it can respond to those with its own criteria for judgment, focusing on 'technical' aspects that require specialized knowledge-in science, professional practices, and artistic productions alike.

Following a market-oriented rationale, profitability, measured on the basis of sales figures for artworks and uses for services, introduces heteronomous principles that might be detrimental to the quality of products in that they lead to compromises aimed at accommodating the tastes of lay publics. Here we must effectively distinguish between the three configurations defined by Johnson. In the case of professionalism, the argument of autonomy can be hijacked to the detriment of clients' interests, who are often helpless in the face of the authority of specialists. The case of heavy dependence on demand from corporations or the state is 
à la demande d'entreprises ou de l'État est un cas d'hétéronomie structurelle. C'est dans le troisième cas, celui où la relation entre producteurs et consommateurs est médiatisée par les intermédiaires (sur cette catégorie, voir Lizé, Naudier, Roueff 2011 ; Jeanpierre \& Roueff 2014), que se pose la question de l'autonomie, dans la mesure où ces derniers ont des intérêts économiques qu'ils peuvent faire peser sur la sélection des produits ou des services en amont et sur le processus de production lui-même, comme on l'a dit.

Le recours fréquent de ces intermédiaires à l'argument des préférences des consommateurs, présenté comme démocratique, contre le prétendu élitisme des créateurs expérimentaux et de leurs défenseurs, est un subterfuge rhétorique développé par les industries culturelles pour justifier des choix orientés par la quête du profit davantage que par le souci de satisfaire une demande dans ce marché de l'offre, ce que confirment les stratégies agressives d'occupation de l'espace des chaînes de librairies par les grands groupes d'édition (places payantes en vitrine ou près de la caisse) pour damer le pion aux concurrents (Thompson 2010). Les concentrations autour de ces grands groupes, dans les industries cinématographique, musicale et éditoriale, menacent ainsi les logiques autonomes des champs de production culturelle en les reléguant aux marges du système et en relativisant le verdict des instances de consécration spécifiques (Bourdieu 1999b ; Duval 2017). II a été montré que les prix littéraires, eux-mêmes d'ores et déjà régulièrement accusés de compromissions pour conserver leur résonance médiatique, ont un impact moindre sur les listes de best-sellers aux États-Unis, pays où le processus de rationalisation dans l'édition est très avancé, qu'en France, où les prix ont encore un vaste retentissement (Verboord 2011). Ce phénomène est révélateur des stratégies de certains intermédiaires pour contourner le verdict des instances spécifiques afin de promouvoir la logique de marché. one of structural heteronomy. The question of autonomy is raised in the third case, in which the relation between producer and consumer is mediated by intermediaries (on that category, see Lizé, Naudier, Roueff 2011; Jeanpierre \& Roueff 2014), as the latter have economic interests that they may put in the balance during the upstream process of selection of products and services and during the production process itself.

These intermediaries frequently put forward the allegedly democratic argument of consumers' preferences versus the supposed elitism of experimental creators and their supporters-a rhetorical trick developed by the cultural industries to justify profit-oriented rather than demand-oriented choices, as exemplified by the aggressive strategies of the largest publishing groups to showcase their books in chain bookstores (by paying for space in window displays or near registers) to outperform the competition (Thompson 2010). Concentration around these large conglomerates in the film, music, and publishing industries thus threatens the autonomous logics of the fields of cultural production by confining them to the sidelines and mitigating the verdict of specific instances of consecration (Bourdieu 1999b; on film, Duval 2017). Research has shown that literary awards, which have themselves been regularly accused of compromising to retain their media sway, have less impact on bestseller lists in the US-a country where the rationalization process in the publishing sector is very advanced-than in France, where these awards are still influential (Verboord 2011). This phenomenon is revelatory of the ways in which some intermediaries pursue strategies to bypass the verdict of the field's authorities and promote a market-driven approach. 
Les interprétations, appropriations et usages politiques des productions culturelles et scientifiques ont fait l'objet de nombreux travaux. Les producteurs culturels ont dû lutter pour conquérir leur autonomie face à la censure et sont encore confrontés à des restrictions à la liberté d'expression dans maints endroits (sur le cas des écrivains en France depuis le début du XIX ${ }^{\mathrm{e}}$ siècle, voir Sapiro 2011). Concernant leur réception, notons que si les producteurs culturels peuvent avoir intérêt à laisser planer une ambiguïté pour échapper à des sanctions ou pour toucher un public plus divers, les appropriations sont facilitées lorsque leurs réalisations sont détachées du contexte de leur production, par le déplacement dans l'espace ou dans le temps (Bourdieu 2002). L'exemple des usages politiques des théories de la justice en France est à ce titre paradigmatique. Significativement, l'intégration de Rawls au canon philosophique en France est passée par un travail de dépolitisation (Hauchecorne 2019).

Si les processus de consécration et/ou de construction des réputations sont désormais bien étudiés, c'est moins le cas pour la canonisation, qui assure aux œuvres le statut de classiques leur permettant de survivre à leurs conditions de production, malgré la réflexion pionnière du formaliste russe Victor Chlovski sur la stratification des systèmes littéraires en éléments canoniques et non canoniques, développée ensuite par Even-Zohar (2005) dans le cadre de sa théorie du polysystème. On doit à Alain Viala (1993) une réflexion sur ce qu'est un classique. La déconstruction du canon européen depuis les années 1980 a toutefois donné lieu à des recherches sur les conditions inégales d'accès à la reconnaissance (sur le cas des écrivains francophones issus d'Afrique subsaharienne, voir l'étude très complète de Claire

Ducournau [2017]).
The political interpretations, appropriations, and uses of cultural and scientific productions have been extensively studied. Cultural producers had to fight to conquer their autonomy in the face of censorship and still suffer from restrictions of their freedom of expression in many places (on writers in France since the early nineteenth century, see Sapiro 2011). Regarding reception, while cultural producers may have an interest in leaving things ambiguous to avoid punishment or may reach out to a more diverse audience, appropriations are facilitated when their works are detached from their context of production, through a shift in time or space (Bourdieu 2002). The political uses of theories of justice in France are the ultimate illustration of this. Significantly, Rawls' introduction to the philosophical canon in France involved a depoliticization process (Hauchecorne 2019).

While the processes of consecration and/or construction of reputations are well known by now, canonization, which gives works the classic status that allows them to survive their conditions of production, has been less studied, despite the pioneering examination by Russian formalist Viktor Shklovsky on the stratification of literary systems into canonical and non-canonical elements, then expanded upon by Even-Zohar (2005) in his polysystem theory. We owe Alain Viala (1993) a reflection on what a classic is. Since the 1980s, the deconstruction of the European canon has inspired studies on the unequal conditions of access to recognition (on French-language writers from sub-Saharan Africa, comprehensive research is found in Ducournau 2017). 
En effet, la revendication d'autonomie a, tout comme la professionnalisation, également servi dans nombre de cas de justification lettrée pour exclure du canon des producteurs marginalisés en raison de leur sexe et/ou de leur origine sociale, ethnique, religieuse ou nationale ou à tout le moins minimiser leur contribution (sur l'exclusion des femmes écrivains françaises de l'entre-deux-guerres du canon littéraire, voir Milligan 1996). Ainsi l'autonomisation d'un champ philosophique dans la seconde moitié du XVIII siècle s'opère à travers l'invention par les kantiens d'une nouvelle forme d'écriture de l'histoire de la philosophie, qui la dissocie des doctrines de salut, excluant par là même tout l'héritage non occidental (Park 2014)

Cette même forme d'élitisme distinctif se réclame parfois de la coupure avec le public des profanes au nom de l'autonomie, en faisant valoir le désintéressement du jugement esthète des détenteurs de capital culturel, conformément à la théorie kantienne, contre l'utilitarisme de ceux qui en sont dépourvus (pour le cas de la lecture, voir Sapiro 2011). Les approches marxistes parlaient à ce propos de mystification des classes populaires et d'aliénation de la conscience, à l'exception des fondateurs des Cultural Studies qui ont remis en cause ces thèses en distinguant d'une part culture de masse et culture populaire (Williams 1974), et en contestant de l'autre la thèse de l'identification qui sous-tend l'idée d'aliénation (Hoggart 1970). Qui plus est, la sociologie du goût et des usages remet en cause cette dichotomie, au profit d'une réflexion sur les homologies structurales (Lizé \& Roueff 2010) et la diversité des usages sociaux de productions culturelles : Gérard Mauger et Claude Poliak (1998) montrent ainsi que la lecture esthète n'est qu'une forme d'appropriation parmi d'autres intérêts : divertissement, éducation et salut.
Indeed, the claim of autonomy, just like professionalization, has also in many cases served as a lettered justification for excluding producers from the canon, marginalized for reasons of gender and/ or social, ethnic, religious or national origin (sometimes this has meant downplaying their contributions; on the exclusion of interwar female French writers from the literary canon, see Milligan 1996). Thus, the autonomization of a philosophical field in the second half of the eighteenth century was characterized by the invention of a new form of philosophy history writing by the Kantians, which dissociated it from salvation doctrines, thereby excluding all the non-Western heritage (Park 2014).

The same form of distinctive elitism sometimes draws on the argument that there must be a break from lay audiences in the name of autonomy, by affirming the disinterestedness of the aesthetic judgment of cultural capital holders, in accordance with Kantian theory, against the utilitarianism or lack of distance of those deprived of that capital (on reading, see Sapiro 2011). Marxist approaches saw in this alleged lack of distance an expression of the mystification of the working classes and the alienation of consciousness, with the exception of the founders of Cultural Studies, who challenged these theses first by making a distinction between mass and popular culture (Williams 1974), and second by disputing the thesis of identification that underlies the idea of alienation (Hoggart 1970). The sociology of taste and uses then reconsidered this dichotomy, favouring a reflection on structural homologies (Lizé \& Roueff 2010) and the diversity of the social uses of cultural productions: for instance, Gérard Mauger et Claude Poliak (1998) showed that "aesthetic reading" is only one form of appropriation among a range of other interests: entertainment, education, and salvation. 


\section{Conclusion}

Si le concept d'autonomie relève de traditions différentes et assez incompatibles, une synthèse raisonnée de ces approches peut donc se révéler féconde pour explorer le fonctionnement des espaces de production des biens symboliques. II serait aussi intéressant d'explorer les zones où ces définitions entrent en concurrence dans la réalité. Par exemple, entre autonomie professionnelle et autonomie au sens de la théorie des champs (voir l'article de Myrtille Picaud dans ce numéro). Ainsi, la tension entre revendications professionnelles et aspirations à l'autonomie par rapport à l'État et au marché entre en contradiction dans le champ littéraire, où la reconnaissance professionnelle repose sur les revenus et non sur un jugement de qualité (Sapiro \& Gobille 2006 ; Sapiro 2016)

Plus généralement, comme on l'a suggéré ailleurs (Sapiro 2006), il n'y a pas de lien de nécessité entre professionnalisation et autonomie, la première relevant de logiques de corps qui peuvent être plus ou moins contrebalancés par des effets de champ. Les exemples des ingénieurs et professeurs du Troisième Reich, ou ceux de producteurs intellectuels et artistiques en Union soviétique, professionnalisés par l'État qui a centralisé et étatisé leur production pour mieux la contrôler et la subordonner à des fins de propagande, montrent qu'on gagnerait à se dégager de l'idéologie professionnelle pour mieux étudier concrètement l'organisation et les pratiques, y compris celles d'exclusion ou de restriction d'individus en raison de leur sexe ou de leurs origines géographiques, nationales, sociales ou ethniques. II en va de même des contraintes imposées par le marché, l'hétéronomie pouvant même favoriser la professionnalisation, comme l'illustre le cas paradigmatique des blockbusters ou des best-sellers.

\section{Conclusion}

While the concept of autonomy stems from different, rather incompatible traditions, an informed synthesis of these approaches may be fruitful to explore how spaces of production of symbolic goods operate. It would also be interesting to explore areas where these definitions compete in reality-for instance, professional autonomy versus autonomy in the sense of field theory (see Picaud on this subject). Thus, professional claims and aspirations to autonomy from the state and the market are at odds in the literary field, where professional recognition comes from income, not from quality judgments (Sapiro \& Gobille 2006; Sapiro 2016).

More broadly, as I have suggested elsewhere (Sapiro 2006), there is no relationship of necessity between professionalization and autonomy, as the former depends on corps rationales that may be offset to various degrees by field effects. The examples of the engineers and teachers of the Third Reich and intellectual and artistic producers in the Soviet Union, professionalized by the state, who centralized and nationalized their production so that they could better control it and use it for propaganda purposes, shows that we stand to benefit from moving away from professional ideology in order to better study the organization and its practices, including those consisting in excluding or restricting individuals for reasons of gender or geographical, national, social, or ethnic origin. The same applies to market constraints; heteronomy may in fact even favour professionalization, as in the paradigmatic cases of blockbusters and bestsellers. 
Qui plus est, par-delà les contraintes extérieures, l'autonomie de la raison et de la création peut être mise au service des pouvoirs et servir à justifier la domination, comme l'ont fait nombre de professions organisées (médecins, juristes) ou d'idéologues et d'experts qui se recrutent aussi bien dans les rangs de la fonction publique, au sein des universités, que parmi les producteurs « indépendants ». Par conséquent, l'autonomie de la raison critique, ne répondant pas à une demande externe mais agissait au nom de sa conscience et de ses valeurs propres (vérité, justice), doit être distinguée comme une forme spécifique d'exercice de l'autonomie intellectuelle, susceptible de faire émerger des formes symboliques alternatives voire oppositionnelles.

Enfin, la réflexion sur les professions comme celle sur les champs pose non seulement la question des luttes de concurrences liées à la division du travail et à la reconnaissance sociale d'un domaine de compétences (processus de spécialisation), mais aussi celle des frontières géographiques. Or l'autonomie nationale n'est pas toujours synonyme d'autonomie du champ par rapport au pouvoir. Certes, à l'instar de l'organisation professionnelle, l'autonomisation des champs a été liée à l'émergence des États-nations et à la concurrence entre eux, et en même temps, elle les déborde par définition, par la logique de marché pour la production culturelle, par la circulation des savoirs et des modèles pour les professions, cette circulation étant plus ou moins régulée par les États (équivalences), par des accords internationaux comme la convention de Berne sur le droit d'auteur, ou par des organisations internationales comme l'Unesco, ainsi que par des associations professionnelles internationales (Sapiro 2013). Cependant, Pascale Casanova (1999) a montré que c'est par un arrachement à leur implication dans la construction des identités nationales que les écrivains ont affirmé leur autonomie, souvent grâce à l'importation de modèles étrangers. Et, comme l'avancent Bourdieu (1985b) et Paul Aron
Furthermore, beyond external constraints, the autonomy of reason and creation can be placed at the service of authorities and serve to justify domination, as has occurred in many professions (doctors, lawyers, etc.) and with ideologues and experts (both civil servants in universities and "independent" producers). And one should distinguish the autonomy of critical reason, which is not exercised in response to an external demand, but in the name of one's own conscience and values (truth, justice), as a specific form of exercise of intellectual autonomy, liable to make alternative, or even oppositional symbolic forms emerge.

Lastly, both the reflections on professions and fields raise not only the question of competitive struggles over the division of labour and the social recognition of an area of competence (the specialization process), but also that of geographical borders. As it happens, national autonomy does not always mean autonomy from power. Admittedly, like the organization of professions, the autonomization of fields has been linked to the emergence of nation-states and the competition between them, and at the same time, it extends beyond that scale by definition, through the market approach to cultural production, the circulation of knowledge and models for the professions, regulated to varying degrees by states (equivalence), international agreements such as the Berne Convention on copyright, or the ones devised by international bodies, Unesco, and international professional groups (Sapiro 2013). Yet Pascale Casanova (1999) showed that writers asserted their autonomy by turning their backs on their involvement in the construction of national identities, often by importing foreign models. As Bourdieu (1985b) and Paul Aron (2005) demonstrated regarding Belgian literature, the presence of national instances of diffusion and consecration is not enough for an autonomous field to form, as the most autonomous pole in the Belgian field still pursues consecration in Paris. 
(2005) à propos de la littérature belge, il ne suffit pas d'avoir des instances de diffusion et de consécration nationales pour que se constitue un champ autonome, le pôle le plus autonome du champ belge recherchant toujours la consécration parisienne.

Gisèle Sapiro

EHESS - Centre européen de sociologie et de science politique-Centre de sociologie européenne (Cessp-CSE)

\section{Références bibliographiques}

Aввотт Andrew (1988). The System of Professions. An Essay on the Division of Expert Labor. Chicago, The University of Chicago Press.

Adorno Theodor W. (2009). Notes sur la littérature [1958], trad. Sibylle Muller. Paris, Flammarion, « Champs ».

AlthUSSER Louis (1970). « Idéologie et appareils idéologiques d’État (Notes pour une recherche) 》 [La Pensée, $\left.\mathrm{n}^{\circ} 151\right]$, Positions (1964-1975). Paris, Les Éditions sociales, $1976: 67-125$.

Althusser Louis et al. (1965). Lire Le Capital. Paris, Maspéro.

Aron Paul (2005). « La littérature en Belgique francophone de 19301960 : débats et problèmes autour d'un "sous-champ" ». In EINFALT Michael, ERzgräBer Ursula, EtTE Ottmar, Sıck Franziska (dir.). Intégrité intellectuelle. Mélanges en l'honneur de Joseph Jurt. Memmingen, Universitätsverlag Winter Heidelberg : 417-428.

Aron Paul, Matontı Frédérique, SAPIRo Gisèle (dir.) (2002). « Le réalisme socialiste en France ». Sociétés \& Représentations, 15.

BeCKER Howard S. (1988). Les Mondes de l'art. Paris, Flammarion.

Bourdieu Pierre (1966). «Champ intellectuel et projet créateur ». Les Temps Modernes, $246: 865-906$
Gisèle Sapiro

EHESS - Centre européen de sociologie et de science politique-Centre de sociologie européenne (Cessp-CSE)

\section{References}

Aввотт Andrew (1988). The System of Professions. An Essay on the Division of Expert Labor. Chicago, The University of Chicago Press.

Adorno Theodor W. (1992). Notes to literature. New York, Colombia University Press.

Althusser Louis (1984). "Ideology and Ideological State Apparatuses." Essays on ideology. London/New York, Verso.

Althusser Louis et al. (2015). Reading Capital. The Complete Edition Translated in English by Ben Brewster and David Fernbach. London/New York, Verso.

Aron Paul (2005). "La littérature en Belgique francophone de 19301960: débats et problèmes autour d'un "sous-champ." In EINFALT Michael, ERzGräBer Ursula, ETTE Ottmar, Sick Franziska (eds.). Intégrité intellectuelle. Mélanges en l'honneur de Joseph Jurt. Memmingen, Universitätsverlag Winter Heidelberg: 417-428.

Aron Paul, Matontı Frédérique, SapiRo Gisèle (eds.) (2002). "Le réalisme socialiste en France." Sociétés \& Représentations, 15.

BeCkeR Howard S. (1982). Art Worlds. Berkeley/Los Angeles/London, University of California Press. 
Bourdieu Pierre (1971). "Le marché des biens symboliques 》. L'Année sociologique, 22(1), p. 49-126.

Bourdieu Pierre (1977). «Sur le pouvoir symbolique ». Annales. Économies, sociétés, civilisations, 32(3) : 405-411.

Bourdieu Pierre (1984). Questions de sociologie [1980]. Paris, Minuit.

Bourdieu Pierre (1985a). «Effet de champ et effet de corps », Actes de la recherche en sciences sociales, $59: 73$.

BouRdieu Pierre (1985b). « Existe-t-il une littérature belge ? Limites d'un champ et frontières politiques », Etudes de lettres, III : 3-6.

Bourdieu Pierre (1988). L'Ontologie politique de Martin Heidegger. Paris, Minuit.

Bourdieu Pierre (1991). "Le champ littéraire ». Actes de la recherche en sciences sociales, 89 : 4-46.

Bourdieu Pierre (1992). Les Règles de l'art. Genèse et structure du champ littéraire, Paris, Seuil.

Bourdieu Pierre (1994). «Pour une science des œuvres ». In Raisons pratiques. Sur la théorie de l'action. Paris, Seuil : 59-98.

Bourdieu Pierre (1999a). "Le fonctionnement du champ intellectuel », Regards sociologiques, 17-18:5-27.

BOURDIEU Pierre (1999b). " Une révolution conservatrice dans l'édition 》. Actes de la recherche en sciences sociales, 126-127 : 3-28.

Bourdieu Pierre (2001). Science de la science et réflexivité. Cours du Collège de France 2000-2001. Paris, Raisons d'agir.
BOURDIEU Pierre (1969). "Intellectual Field and Creative Project." Social Science Information, 8: 89-119.

Bourdieu Pierre (1977). "Sur le pouvoir symbolique." Annales. Économies, sociétés, civilisations, 32 (3): 405-411.

\section{Bourdieu Pierre (1984). Questions de sociologie [1980], Paris, Minuit.}

Bourdieu Pierre (1985a). "Effet de champ et effet de corps." Actes de la recherche en sciences sociales, 59: 73.

BouRdieu Pierre (1985b). "Existe-t-il une littérature belge ? Limites d'un champ et frontières politiques." Études de lettres, III, 3-6.

Bourdieu Pierre (1985c). "The Market of Symbolic Goods." Poetics, 14(1):13-24

Bourdieu Pierre (1991). The Political Ontology of Martin Heidegger. Translated in English by Peter Collier. Palo Alto, Stanford University Press. Bourdieu Pierre (1991). "Le champ littéraire." Actes de la recherche en sciences sociales, 89: 4-46.

Bourdieu Pierre (1992). "Principles for a Sociology of Cultural Works." In Kemals Salim, Gaskell Ivan (eds). Explanation and Value in the Arts. Cambridge, Cambridge University Press.

Bourdieu Pierre (1996). The Rules of Art. Genesis and Structure of the Literary Field. Translated in English by Susan Emanuel. Cambridge: Polity Press.

Bourdieu Pierre (1999a). "Le fonctionnement du champ intellectuel." Regards sociologiques, 17-18: 5-27.

Bourdieu Pierre (1999b). "The Social Conditions of the International Circulation of Ideas." In Shusterman Richard (ed.). Bourdieu: A Critical Reader. Oxford/Malden, Wiley-Blackwell: 220-228. 
BOURDieu Pierre (2002). "Les conditions sociales de la circulation internationale des idées ». Actes de la recherche en sciences sociales, $145: 3-8$.

Bourdieu Pierre (2013). Manet, une révolution symbolique. Paris, Seuil/ Raisons d'agir.

Bucher Rue \& Anselm Strauss (1961). «Professions in Process 》. American Journal of Sociology, 66(4): 325-334.

Casanova Pascale (1999). La République mondiale des letters. Paris, Seuil.

Cassagne Albert (1997). La Théorie de l'art pour l'art en France chez les derniers romantiques et les premiers réalistes [1906]. Paris, Champ Vallon.

Cassiren Ernst (1972). [2001, Philosophie der symbolischen Formen, Bd 1 : Die Sprache (1923). In Gesammelte Werke, Bd. 11. Meiner, Hamburg], La Philosophie des formes symboliques, t. 1 : Le langage. Paris, Minuit.

Chapoulie Jean-Michel (1973). « Sur l'analyse sociologique des groupes professionnels ». Revue française de sociologie, 14(1) : 86-114.

Coulangeon Philippe (1999). «Les musiciens de jazz : les chemins de la professionnalisation ». Genèses, $36: 54-68$.

Delporte Christian (1998). Les Journalistes en France (1880-1950). Naissance et construction d'une profession. Paris, Seuil.

Dragomir Lucia (2007). L'Union des écrivains. Une institution transnationale à l'Est. Paris, Belin.

Duval Julien (2016). Le Cinéma au $x x^{e}$ siècle. Entre loi du marché et règles de l'art. Paris, CNRS Éditions.
BouRdieu Pierre (2004). Science of Science and Reflexivity. Chicago, University of Chicago Press.

BouRdieu Pierre (2008). "A Conservative Revolution in Publishing." Translation Studies, 1: 123-153

Bourdieu Pierre (2017). Manet. A Symbolic Revolution. Translated in English by Peter Collier \& Margaret Rigaud-Drayton. Cambridge, Polity Press.

Bucher Rue \& Anselm Strauss (1961). "Professions in Process." American Journal of Sociology, 66(4): 325-334.

Casanova Pascale (2005). The World Republic of Letters. Translated in English by M.B. DeBevoise. Cambridge, Harvard University Press.

Cassagne Albert (1997). La Théorie de l'art pour l'art en France chez les derniers romantiques et les premiers réalistes [1906]. Paris, Champ Vallon.

Cassiren Ernst (1953). The Philosophy of Symbolic Forms, vol. I: The Language. New Haven, Yale University Press.

ChAPOULIE Jean-Michel (1973). "Sur l'analyse sociologique des groupes professionnels." Revue française de sociologie, 14(1): 86-114.

Coulangeon Philippe (1999). "Les musiciens de jazz: les chemins de la professionnalisation." Genèses, 36: 54-68.

Delporte Christian (1998). Les Journalistes en France (1880-1950). Naissance et construction d'une profession. Paris, Seuil.

Dragomir Lucia (2007). L'Uniondes écrivains. Une institution transnationale à l'Est. Paris, Belin. 
Even-Zohar Itamar (1990). « Polysystem Studies », Poetics Today, 11(1).

FabianI Jean-Louis (1988). Les Philosophes de la République. Paris, Minuit.

Fauconnet Paul (1928). La Responsabilité. Étude de sociologie. Paris, Alcan.

Freidson Eliot (1984). La Profession médicale, trad. Andrée Lyotard-May et Catherine Malamoud. Paris, Payot.

FrEIDson Eliot (1986). « Les professions artistiques comme défi à l'analyse sociologique ». Revue française de sociologie, 27(3) : 431-444.

Freidson Eliot (2001). Professionalism, the Third Logic. On the Practice of Knowledge. Chicago, The University of Chicago Press.

Goode William J. (1957). « Community Within a Community: The Professions », American Sociological Review, 22(2) : 194-200.

Garrard John \& Garrard Carol (1990). Inside the Soviet Writers' union. New York/Londres, The Free Press/Macmilan.

Goldmann Lucien (1955). Le Dieu caché. Étude sur la vision tragique dans les Pensées de Pascal et dans le théâtre de Racine. Paris, Gallimard.

GoldSTEIN Jan (1984). " "Moral contagion" : a professional ideology of medicine and psychiatry in eighteenth- and nineteenth-century France ». In Geison Gerald L., Professions and the French State 1700-1900. Philadelphie, University of Pennsylvania Press : 181-222.

Gullbaut Serge (2006). Comment New York vola l'idée d'art moderne. Expressionnisme abstrait, liberté et guerre froide. Paris, Hachette.
Duval Julien (2016). Le Cinéma au $x x^{e}$ siècle. Entre loi du marché et règles de l'art. Paris, CNRS Éditions.

Even-Zohar Itamar (1990). "Polysystem Studies.' Poetics Today, 11(1).

FabianI Jean-Louis (1988). Les Philosophes de la République. Paris, Minuit.

Fauconnet Paul (1928). La Responsabilité. Étude de sociologie. Paris, Alcan.

Freidson Eliot (1970). Profession of Medicine. New York, Dodd \& Mead.

FreidSON Eliot (1986). "Les professions artistiques comme défi à l'analyse sociologique." Revue française de sociologie, 27(3): 431-444.

Freidson Eliot (2001). Professionalism, the Third Logic. On the Practice of Knowledge. Chicago, The University of Chicago Press.

Goode William J. (1957). "Community Within a Community: The Professions." American Sociological Review, 22(2): 194-200.

GarRaRd John \& Garrard Carol (1990). Inside the Soviet Writers' Union. New York/London, The Free Press/Macmilan.

Goldmann Lucien (2013) [1955]. The Hidden God. A Study of Tragic Vision in the Pensées of Pascal and the Tragedies of Racine. Translate in English by Philip Thody. London, Routledge.

GoldSTEIN Jan (1984). "'Moral contagion': a professional ideology of medicine and psychiatry in eighteenth- and nineteenth-century France." In Geison Gerald L., Professions and the French State 1700-1900. Philadelphie, University of Pennsylvania Press: 181-222. 
Hauchecorne Mathieu (2019). La Gauche américaine en France. La réception française de John Rawls et des théories de la justice (19712010). Paris, CNRS Éditions.

Henry Odile (1992). « Entre savoir et pouvoir. Les professionnels de l'expertise et du conseil ». Actes de la recherche en sciences sociales, $95: 37-54$.

Henry Odile (2012). Les Guérisseurs de l'économie. Socio-genèse du métier de consultant (1900-1944). Paris, CNRS Éditions.

Hoggart Richard (1970) [1957]. La Culture du pauvre. Étude sur le style de vie des classes populaires en Angleterre, trad. Jean-Claude Passeron. Paris, Minuit.

JAMESON Frederic (2012). L'Inconscient politique. Le récit comme acte socialement symbolique, trad. Nicolas Vieillecazes. Paris, Questions théoriques.

Jarausch Konrad H. (1990). The Unfree Professions. German Lawyers, Teachers and Engineers, 1900-1950. New York, Oxford University Press.

Johnson Terence J. (1972). Professions and Power. Londres The Macmillan press.

Kantorowicz Ernst (1989) [1957]. Les Deux Corps du roi, trad. JeanPhilippe Genet et Nicole Gene. Paris, Gallimard.

KarPIK Lucien (1995). Les Avocats. Entre l'État, le public et le marché. $x I^{e}-x X^{e}$ siècle. Paris, Gallimard.

KARPIK Lucien (2007). L'Économie des singularités. Paris, Gallimard.

JeANPIERRE Laurent \& RouefF Olivier (dir.) (2014). La Culture et ses intermédiaires. Dans les arts, le numérique et les industries créatives. Paris, Archives contemporaines.
GuILBAUt Serge (2006). Comment New York vola l'idée d'art moderen. Expressionisme abstrait, liberté et guerre froide. Paris, Hachette.

HaucheCoRne Mathieu (2019). La Gauche américaine en France. La réception française de John Rawls et des théories de la justice (19712010). Paris, CNRS Éditions.

HenRy Odile (1992). "Entre savoir et pouvoir. Les professionnels de l'expertise et du conseil." Actes de la recherche en sciences sociales, 95: 37-54.

Henry Odile (2012). Les Guérisseurs de l'économie. Socio-genèse du métier de consultant (1900-1944). Paris, CNRS Éditions.

Hoggart Richard (1957). The Uses of Literacy. Aspects of Working-Class Life with Special References to Publications and Entertainments. London, Chatto and Windus.

JAMESON Frederic (1981). The Political Unconscious. Narrative as a Socially Symbolic Act. New York, Cornell UP.

Jarausch Konrad H. (1990). The Unfree Professions. German Lawyers, Teachers and Engineers, 1900-1950. New York, Oxford University Press.

Johnson Terence J. (1972). Professions and Power. London, The Macmillan press.

Kantorowicz Ernst (1957). The King's Two Bodies. A Study in Mediaeval Political Theology. Princeton, Princeton University Press.

Kantorowicz Ernst (1989) [1957]. Les Deux Corps du roi. Traduit en français par Jean-Philippe Genet et Nicole Gene. Paris, Gallimard.

KARPIK Lucien (1995). Les Avocats. Entre l'État, le public et le marché. $x I I I^{e}-x x^{e}$ siècle. Paris, Gallimard. 
Lebaron Frédéric (2000). La Croyance économique. Les économistes entre science et politique. Paris, Seuil.

LÉONARD Jacques (1987). La Médecine entre savoir et pouvoir. Paris, Aubier-Montaigne.

LePERLIER Tristan (2018). Algérie, les écrivains dans la décennie noire. Paris, CNRS Éditions.

Lizé Wenceslas, Naudier Delphine, Roueff Olivier (2011). Intermédiaires du travail artistique. À la frontière de l'art et du commerce. Paris, Ministère de la Culture - DEPS, « Questions de culture ».

LIZÉ Wenceslas \& Roueff Olivier (2010). « La fabrique des goûts 》. Actes de la recherche en sciences sociales, 181-182: 4-11.

LuHmanN Niklas (2011). Systèmes sociaux. Esquisse d'une théorie générale. Laval, Presses de l’Université Laval.

LuKÀcs Georg (1999). Balzac et le réalisme français [1951], trad. de l'allemand Paul Laveau. Paris, La Découverte.

Macdonald Keith M. (1995). The Sociology of the Professions. Londres, Sage.

MACherey Pierre (1971). Pour une théorie de la production littéraire. Paris, Maspero.

MANnHEIm Karl (2006) [1929]. Idéologie et Utopie, trad. de l'allemand JeanLuc Evard et Olivier Mannoni. Paris, Maison des sciences de l'homme.

Masseau Didier (1994). L'Invention de l'intellectuel dans l'Europe du XVIII siècle. Paris, Presses Universitaires de France.
KARPIK Lucien (2007). L’Économie des singularités. Paris, Gallimard.

Jeanpierre Laurent \& Roueff Olivier (eds.) (2014). La Culture et ses intermédiaires. Dans les arts, le numérique et les industries créatives. Paris, Archives contemporaines.

LeBARON Frédéric (2000). La Croyance économique. Les économistes entre science et politique. Paris, Seuil.

LÉONARD Jacques (1987). La Médecine entre savoir et pouvoir. Paris, Aubier-Montaigne.

Leperlier Tristan (2018). Algérie, les écrivains dans la décennie noire. Paris, CNRS Éditions.

Lizé Wenceslas, NaUdier Delphine, Roueff Olivier (2011). Intermédiaires du travail artistique. À la frontière de l'art et du commerce. Paris, Ministère de la Culture/DEPS, "Questions de culture."

LızÉ Wenceslas \& Roueff Olivier (2010). "La fabrique des goûts." Actes de la Recherche en Sciences Sociales, 181-182: 4-11.

LuHmann Niklas (2011). Systèmes sociaux. Esquisse d'une théorie générale. Laval, Presses de l'Université Laval.

LuKÀcs Georg (1999). Balzac et le réalisme français [1951]. Translation from German by Paul Laveau. Paris, La Découverte.

Macdonald Keith M. (1995). The Sociology of the Professions. London Sage.

Macherey Pierre (1971). Pour une théorie de la production littéraire. Paris, Maspero. 
MATONTI Frédérique (2002). « La colombe et les mouches. Frédéric JoliotCurie et le pacifisme des savants ». Politix, $58: 109-140$.

MatontI Frédérique (2005). Intellectuels communistes. Essai sur l'obéissance politique. La Nouvelle Critique (1967-1980). Paris, La Découverte.

Mauger Gérard \& Poliak Claude (1998). « Les usages sociaux de la lecture ». Actes de la recherche en sciences sociales, 123 : 3-24.

MeHLMan Jeffrey (2003). «Paul Valéry, entre craniométrie et critique ». In Éveline Pinto (dir.). L'Écrivain, le savant et le philosophe. La littérature entre philosophie et sciences sociales. Paris, Publications de la Sorbonne : 171-182.

Merton Robert (1996). On Social Structure and Science. Chicago/ Londres, The University of Chicago Press.

Millerson Geoffrey (1998) [1964]. The Qualifying Associations. Londres, Routledge.

MiLligan Jennifer (1996). The Forgotten Generation. French Women Writers of the Interwar Period. New York/Oxford, Berg.

Moulın Raymonde (1967). Le Marché de la peinture en France. Paris, Minuit.

MouLIN Raymonde (1983). «De l'artisan au professionnel : l'artiste. » Sociologie du travail, 25(4) : 388-403.

Moulin Raymonde (2009) [1992]. L’Artiste, l'institution et le marché. Paris, Flammarion.

Muel-Dreyfus Francine (1996). Vichy et l'éternel féminin. Contribution à une sociologie politique de l'ordre des corps. Paris, Seuil.
Mannheim Karl (2006) [1998]. Ideologia and Utopia, Collected Works by Karl Mannheim, vol. 6. London, Routledge.

Masseau Didier (1994). L'Invention de l'intellectuel dans l'Europe du $x$ VIII siècle. Paris, PUF.

MatontI, Frédérique (2002). "La colombe et les mouches. Frédéric JoliotCurie et le pacifisme des savants." Politix, 58: 109-140.

MatontI Frédérique (2005). Intellectuels communistes. Essai sur l'obéissance politique. La Nouvelle Critique (1967-1980). Paris, La Découverte.

Mauger Gérard \& Poliak Claude (1998). "Les usages sociaux de la lecture." Actes de la recherche en sciences sociales, 123: 3-24.

Mehlman Jeffrey (2003). "Paul Valéry, entre craniométrie et critique." In Éveline Pinto (eds.). L'Écrivain, le savant et le philosophe. La littérature entre philosophie et sciences sociales. Paris, Publications de la Sorbonne: 171-182.

Merton Robert (1996). On Social Structure and Science. Chicago/London, The University of Chicago Press.

MiLlerson, Geoffrey (1998) [1964]. The Qualifying Associations. London, Routledge.

Milligan Jennifer (1996). The Forgotten Generation. French Women Writers of the Interwar Period. New York/Oxford, Berg.

Moulin Raymonde (1967). Le Marché de la peinture en France. Paris, Minuit.

Moulin Raymonde (1983). "De l'artisan au professionnel: l'artiste." Sociologie du travail, 25(4): 388-403. 
Park Peter (2014). Africa, Asia, and the History of Philosophy. Racism in the Formation of the Philosophical Canon, 1780-1830. Albany, Suny Press.

PARsons Talcott (1939). «The Professions and Social Structure », Social Forces, 17(4) : 457-467.

PINELL Patrice (2005). « Champ médical et processus de spécialisation ». Actes de la recherche en sciences sociales, 156-157 : 4-36.

Quemin Alain (1997). Les Commissaires-priseurs. La mutation d'une profession. Paris, Anthropos.

Rennes Juliette (2007). Le Mérite et la Nature. Une controverse républicaine : l'accès des femmes aux professions de prestige 18801940. Paris, Fayard.

Robin Régine (1986). Le Réalisme socialiste. Une esthétique impossible. Paris, Payot.

Rотн Guenther (1992). « Interpreting and translating Max Weber ». International Sociology, 7(4): 449-459.

Saint-Jacques Denis \& Viala Alain (1994). « À propos du champ littéraire. Histoire, géographie, histoire littéraire ». Annales. Histoire, sciences sociales, 49(2) : 395-406.

SAPIRO Gisèle (1999). La Guerre des écrivains, 1940-1953. Paris, Fayard.

SAPIRO Gisèle (2003a). "The literary field between the state and the market ». Poetics. Journal of Empirical Research on Culture, the Media and the Arts. 31(5-6) : 441-461.
Moulin Raymonde (2009) [1992]. L'Artiste, l'institution et le marché. Paris, Flammarion.

Muel-Dreyfus Francine (1996). Vichy et l'éternel féminin. Contribution à une sociologie politique de l'ordre des corps. Paris, Seuil.

Park Peter (2014). Africa, Asia, and the History of Philosophy. Racism in the Formation of the Philosophical Canon, 1780-1830. Albany, Suny Press.

PARsons Talcott (1939). "The Professions and Social Structure." Social Forces, 17(4): 457-467.

PINeLL Patrice (2005). "Champ médical et processus de spécialisation." Actes de la recherche en sciences sociales, 156-157: 4-36.

Quemin Alain (1997). Les Commissaires-priseurs. La mutation d'une profession. Paris, Anthropos.

Rennes Juliette (2007). Le Mérite et la Nature. Une controverse républicaine: l'accès des femmes aux professions de prestige 1880-1940. Paris, Fayard.

RoBIn Régine (1986). Le Réalisme socialiste. Une esthétique impossible. Paris, Payot

Rотн Guenther (1992). "Interpreting and translating Max Weber." International Sociology, 7(4): 449-459.

Saint-Jacques Denis \& Viala Alain (1994). "À propos du champ littéraire. Histoire, géographie, histoire littéraire." Annales. Histoire, sciences sociales, 49(2): 395-406.

SAPIRO Gisèle (2014). The French Writers' War. Translate in English by Vanessa Doriott Anderson and Dorrit Cohn. Duham, Duke UP. 
SAPIRO Gisèle (2003b). «Autonomie esthétique, autonomisation littéraire ». In Lagrave Rose-Marie \& Encrevé Pierre (dir.). Travailler avec Bourdieu. Paris, Flammarion : 289-296.

SAPIRO Gisèle (2003c). "Entre individualisme et corporatisme : les écrivains dans la première moitié $d u x^{e}$ siècle ". In KaPLAN Steven \& MinaRD Philippe (dir.). Corporations et corporatisme en France, $x$ VIII ${ }^{e}$ $x x^{e}$ siècles. Paris, Belin : 279-314.

SAPIRO Gisèle (2006). " Les professions intellectuelles entre l'État, l'entrepreneuriat et l'industrie ». Le Mouvement social, 214 : 3-18.

SAPIRO Gisèle (2009). « Modèles d'intervention politique des intellectuels : le cas français ". Actes de la recherche en sciences sociales, 176-177 : 8-31.

SAPIRo Gisèle (2011). La Responsabilité de l'écrivain. Littérature, droit et

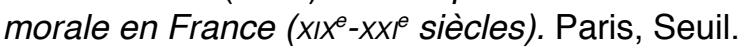

SAPIRO Gisèle (2013). " Le champ est-il national ? La théorie de la différenciation sociale au prisme de l'histoire globale ". Actes de la recherche en sciences sociales, $200: 70-85$.

SAPIRO Gisèle (2016). « The metamorphosis of modes of consecration in the literary field: Academies, literary prizes, festivals ». Poetics, 59:5-19.

SAPIRO Gisèle (2017). « Une catégorie éthique de l'entendement lettré: le concept de désintéressement ", Silène. [En ligne] [consulté le 30 janvier 2019].

SAPIRO Gisèle \& Gobille Boris (2006). «Propriétaires ou travailleurs intellectuels ? Les écrivains français en quête de statut ». Le Mouvement social, 214 : 119-145 [traduction anglaise : sélection Cairn, 2013].
SAPIRO Gisèle (2003a). "The Literary Field Between the State and the Market." Poetics. Journal of Empirical Research on Culture, the Media and the Arts. 31(5-6), 441-461.

SAPIRo Gisèle (2003b). "Autonomie esthétique, autonomisation littéraire." In Lagrave Rose-Marie \& Encrevé Pierre (eds.). Travailler avec Bourdieu. Paris, Flammarion: 289-296.

SAPIRO Gisèle (2003c). "Entre individualisme et corporatisme: les écrivains dans la première moitié du $x x^{e}$ siècle." In Kaplan Steven \& Minard Philippe (eds.). Corporations et corporatisme en France, $x V \| I I^{e}-x x^{e}$ siècles. Paris, Belin: 279-314.

SAPIRO Gisèle (2006). "Les professions intellectuelles entre l'État, l'entrepreneuriat et l'industrie." Le Mouvement social, 214: 3-18.

SAPIRO Gisèle (2009). "Modèles d'intervention politique des intellectuels: le cas français." Actes de la recherche en sciences sociales, 176-177: 8-31.

SAPIRO Gisèle (2011). La Responsabilité de l'écrivain. Littérature, droit et morale en France ( $x I x^{e}-x x F^{e}$ siècles). Paris, Seuil.

SAPIRO Gisèle (2016). "The Metamorphosis of Modes of Consecration in the Literary Field: Academies, Literary Prizes, Festivals." Poetics, 59: 5-19.

SAPIRO Gisèle (2017). "Une catégorie éthique de l'entendement lettré: le concept de désintéressement." Silène. [Online] [accessed on 30 January 2019].

SAPIRO Gisèle (2018). "Field theory from a transnational perspective." In Medvetz Tom \& Sallaz Jeffrey (eds.). Oxford Handbook of Pierre Bourdieu. Oxford, Oxford University Press: 161-182. 
Sarfatti Larson Magali (1977). The Rise of Professionalism. A Sociological Analysis. Berkeley/Los Angeles/Londres, University of California Press.

SAYRE Robert (2011). La Sociologie de la littérature. Histoire, problématique, synthèse critique. Paris, L'Harmattan.

ScHückING Levin L. (1966) [1931]. The Sociology of Literary Taste, traduit de l'allemand par Brian Battershaw. Londres, Routledge/Kegan Paul.

SIGRIEST Hannes (2004). «The Professions in nineteenth-century Europe ». In Kaelble Hartmut (dir.), The European Way. New York, Berghahn Books.

Smith Harvey L. (1958). « Contingencies of Professional Differentiation ». American Journal of Sociology, 6(4) : 410-414.

Swedberg Richard \& Agevall Ola (2016). The Max Weber Dictionary : Key Words and Central Concepts. Palo Alto, Stanford University Press.

Thompson John (2010). Merchants of Culture. The Publishing Business in the Twenty-First Century. Cambridge, Polity Press.

VerBoord Marc (2011). « Market logic and cultural consecration in French, German and American bestseller lists, 1970-2007. " Poetics. Journal of Empirical Research on Culture, the Media and the Arts, 39(4) : 290-315.

Viala Alain (1985). Naissance de l'écrivain. Sociologie de la littérature à l'âge classique. Paris, Minuit.

VIALA Alain (1988). «Effets de champ, effets de prisme ». Littérature, 70 : 64-72.

VIALA Alain (1993). Qu'est-ce qu'un classique ?. Paris, Klincksieck.

WEBER Max (1984) [1915]. «Zwischenbetrachtung: Theorie der Stufen und Richtungen religiöser Weltablehnung » In Max Weber-Gesamtausgabe:
SAPIRO Gisèle \& GoBILle Boris (2006). "Literary Property Owners or Intellectual Workers? French Writers in Search of a Status." Translated by Cadenza Academic Translations. Le Mouvement social, 214: 119-145. [Online] [accessed on 30 January 2010].

Sarfatti Larson Magali (1977). The Rise of Professionalism. A Sociological Analysis. Berkeley/Los Angeles/London, University of California Press.

SAYRE Robert (2011). La Sociologie de la littérature. Histoire, problématique, synthèse critique. Paris, L'Harmattan.

Schücking Levin L. (1966) [1931]. The Sociology of Literary Taste. Translation from German by Brian Battershaw. London, Routledge \& Kegan Paul.

Sigriest Hannes (2004). "The Professions in nineteenth-century Europe." In KAelble Hartmut (ed.). The European Way. New York, Berghahn Books.

Smith Harvey L. (1958). "Contingencies of Professional Differentiation." American Journal of Sociology, 6(4): 410-414.

Swedberg Richard \& Agevall Ola (2016). The Max Weber Dictionary. Key Words and Central Concepts. Palo Alto, Stanford University Press.

THompson John (2010). Merchants of Culture. The Publishing Business in the Twenty-First Century. Cambridge, Polity Press.

VerBoord Marc (2011). "Market logic and cultural consecration in French, German and American bestseller lists, 1970-2007." Poetics. Journal of Empirical Research on Culture, the Media and the Arts, 39(4): 290-315.

Viala Alain (1985). Naissance de l'écrivain. Sociologie de la littérature à l'âge classique. Paris, Minuit. 
Schriften, Reden, Briefe und Vorlesungen, I/22-2. Tübingen, J.C.B. Mohr (Paul Siebeck) : 367-414.

WEBER Max (1984). "Considération intermédiaire ", trad. de l'allemand Jean-Pierre Grossein. Sociologie des religions. Paris, Gallimard.

WiLliams Raymond (1965) [1961]. The Long Revolution. Harmondsworth, Penguin Books/Chatto and Windus.

Williams Raymond (1974). « On High and Popular Culture ». New Republic, $171: 15$.

WiLliams Raymond (1977). Marxism and Literature. New York, Oxford University Press.

WiLliams Raymond (1981). Culture. Glasgow, Fontana Press.

Williams Raymond (1983) [1958]. Culture and Society. New York Columbia University Press.

Williams Raymond (2009). «Base et superstructure dans la théorie culturelle marxiste », trad. Nicolas Calvé et Étienne Dobenesque. Culture \& Matérialisme. Paris, Les Prairies ordinaires.

Woodmansee Marta (1994). The Author, Art and the Market. Rereading the History of Aesthetics. New York, Columbia University Press.
ViALA Alain (1988). "Effets de champ, effets de prisme." Littérature, 70: 64-72.

ViaLA Alain (1993). Qu'est-ce qu'un classique ? Paris, Klincksieck.

Weber Max (1984). "Zwischenbetrachtung: Theorie der Stufen und Richtungen religiöser Weltablehnung" [1915]. In Max WeberGesamtausgabe: Schriften, Reden, Briefe und Vorlesungen, I/22-2. Tübingen, J.C.B. Mohr (Paul Siebeck): 367-414.

Weber Max (1993) [1963]. "The Relationship of Religion to Politics, Economics, Sexuality, and Art." In The Sociology of Religion. Translated in English by Ephraim Fischoff. Boston, Beacon Press.

WiLliams Raymond (1974). "On High and Popular Culture". New Republic, 171: 15.

WiLliams Raymond (1977). Marxism and Literature. New York, Oxford University Press.

Williams Raymond (1981). Culture. Glasgow, Fontana Press.

Williams Raymond (1983) [1958]. Culture and Society. New York, Columbia University Press.

Williams Raymond (2005). "Base and Superstructure in Marxist Cultural Theory." Culture and Materialism. London, Verso.

Woodmansee Marta (1994). The Author, Art and the Market. Rereading the History of Aesthetics. New York, Columbia University Press. 